\title{
Geodynamic regimes of subduction under an active margin: effects of rheological weakening by fluids and melts
}

\author{
T. V. GERYA ${ }^{1,2}$ AND F. I. MEILICK ${ }^{1}$ \\ ${ }^{1}$ Geophysical Fluid Dynamics Group, Institute of Geophysics, Department of Earth Sciences, Swiss Federal Institute of \\ Technology (ETH-Zurich), Sonneggstrasse, 5, 8092 Zurich, Switzerland (taras.gerya@erdw.ethz.ch) \\ ${ }^{2}$ Department of Geology, Moscow State University, 119899 Moscow, Russia
}

\begin{abstract}
The dynamics of subduction under an active margin are analysed by using a 2D-coupled petrologicalthermomechanical numerical model of an oceanic-continental subduction system. The model includes spontaneous slab bending, dehydration of the subducted crust, aqueous fluid transport, partial melting of both crustal and mantle rocks as well as melt extraction processes resulting in magmatic arc crust growth. Based on our models, the following five geodynamic regimes of subduction, which may potentially form at active margins, are identified: (i) stable subduction with no backarc spreading centre and without plumes in the mantle wedge; (ii) retreating subduction with a focused backarc spreading centre and without plumes; (iii) retreating subduction with distributed intra-arc extension and translithospheric sedimentary plumes; (iv) advancing subduction with underplating (laterally extending) sub-lithospheric plumes; and (v) stable to advancing subduction with stationary (laterally limited) sub-lithospheric plumes. Transitions between these different regimes are mainly caused by the concurrence of rheological weakening effects of (i) aqueous fluids percolating from the subducting slab into the mantle wedge and (ii) melts propagating from the partially molten areas formed in the mantle wedge towards the surface. The aqueous fluids mainly affect the forearc region. Strong fluid-related weakening promotes plate decoupling and reduces subduction drag and thus results in stacking of sediments in the accretion prism. In contrast, reduced weakening by fluids results in strong coupling of the plates and leads to advancing collision-like subduction with enhanced subduction erosion. Thickening of the overriding plate and large sedimentary plumes in the mantle wedge are the consequences. On the other hand, melts, extracted from the hot regions above the slab, rheologically weaken the lithosphere below the arc, which thus controls overriding plate extension and shortening. Strong rheological weakening by melts in combination with weak plate coupling trigger retreating subduction with a pronounced backarc spreading centre. Also, weakening of the continental lithosphere by melts extracted from trans-lithospheric sedimentary plumes generate a weak channel through which these structures may be emplaced into subarc crust. If there is insufficient melt-related weakening, plumes cannot ascend but extend horizontally and thus underplate the lithosphere.
\end{abstract}

Key words: active margin; crustal growth; numerical modelling; rheological weakening; subduction.

\section{INTRODUCTION}

The importance of fluids and melts in the process of subduction is continuously revealed and approved by various geoscientific studies (e.g. Stern, 2002). It is widely accepted that aqueous fluids derived from the subducting plate result in melting of hydrated mantle peridotite, so-called 'flux melting', by lowering the temperature of the wet solidus (e.g. Kushiro et al., 1968; Stolper \& Newman, 1994; Schmidt \& Poli, 1998). The resulting melts lead to arc magmatism and play a major role in the accretion of continental crust, which was differentiated from the mantle during the evolution of the Earth (e.g. Albarede, 1998; Stein \& Ben-Avraham, 2007). Water is also considered to be crucial for the occurrence of plate tectonics on Earth driven by asymmetric one-sided subduction (e.g.,
Mackwell et al., 1998; Regenauer-Lieb et al., 2001; van Thienen et al., 2004; Gerya et al., 2008).

As fluid is released from the subducting slab, it alters the physical-chemical properties of the overlying mantle rocks by lowering their melting temperature, viscosity and density (e.g. Kushiro et al., 1968; Karato \& Wu, 1993; Poli \& Schmidt, 1995; Schmidt \& Poli, 1998). Recently, numerous 2D and 3D numerical studies with thermal-chemical models of subduction have been published that addressed various aspects of geodynamic consequences of fluid and melt in subduction zones, including a low viscosity wedge formation, the asymmetry of terrestrial subduction, small scale convection in the mantle wedge, thermalchemical plume development, magmatic productivity and crustal growth in volcanic arcs etc. (e.g., Gerya et al., 2002, 2006, 2008; Gerya \& Yuen, 2003a; Arcay 


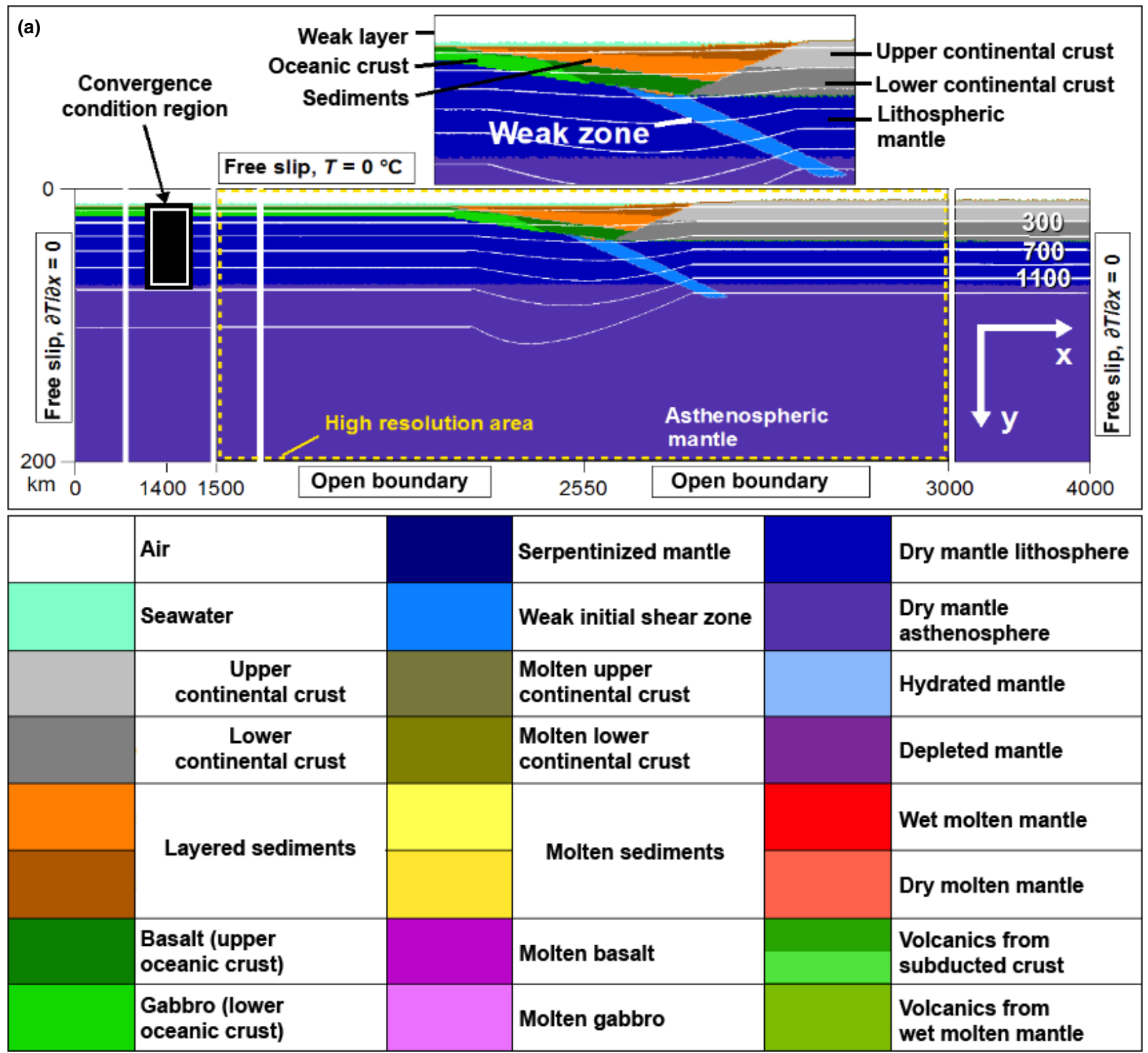

Fig. 1. Initial configuration of the numerical model (a) (see text for details) and stable water content in equilibrium mineral assemblages (i.e. without pore water) for different rock types (b)-(e). (a) Staggered grid resolution is $1001 \times 101$ nodal points, with more than 10 million randomly distributed markers. Grid size is $2 \times 2 \mathrm{~km}$ in the subduction zone area $(1500-3000 \mathrm{~km})$ and $10 \times 2 \mathrm{~km}$ elsewhere. White lines are isotherms in ${ }^{\circ} \mathrm{C}$. Colours indicate materials (e.g. rock type or melt) that appear in subsequent figures. For the sediments and the mantle, two layers with the same physical properties are distinguished using different colours to better illustrate the deformation. (b)-(e) Equilibrium mineral assemblages are computed from thermodynamic data and rock compositions (Gerya et al., 2006) using Gibbs energy minimization (Connolly, 2005). Note that maximal water content in rocks is limited to account for incomplete and heterogeneous hydration (Gerya et al., 2006): sediments $=7.60 \mathrm{wt} \%$; upper oceanic crust $=2.78 \mathrm{wt} \%$; lower oceanic crust $=1.47 \mathrm{wt} \%$; hydrated peridotite $=1.98 \mathrm{wt} \%$.

et al., 2005; Gorczyk et al., 2007; Nikolaeva et al., 2008; Hebert et al., 2009; Zhu et al., 2009; Honda et al., 2010). It was also recently suggested (Ueda et al., 2008; Sizova et al., 2010) that the rheological weakening effects of sublithospheric melts that percolate through the lithosphere may control major transitions in geodynamic styles in the Earth history including the initiation and long-term stability of subduction. This implies that rheological weakening effects from both fluids and melts may be equally important and control subduction styles in different geodynamic situations.

In order to systematically investigate these effects, a series of 2D numerical experiments have been performed with a recently created petrological-thermomechanical model of oceanic-continental subduction (Nikolaeva et al., 2008; Sizova et al., 2010), which includes spontaneous slab bending with free surface and accounts for dehydration and water transport, mantle 

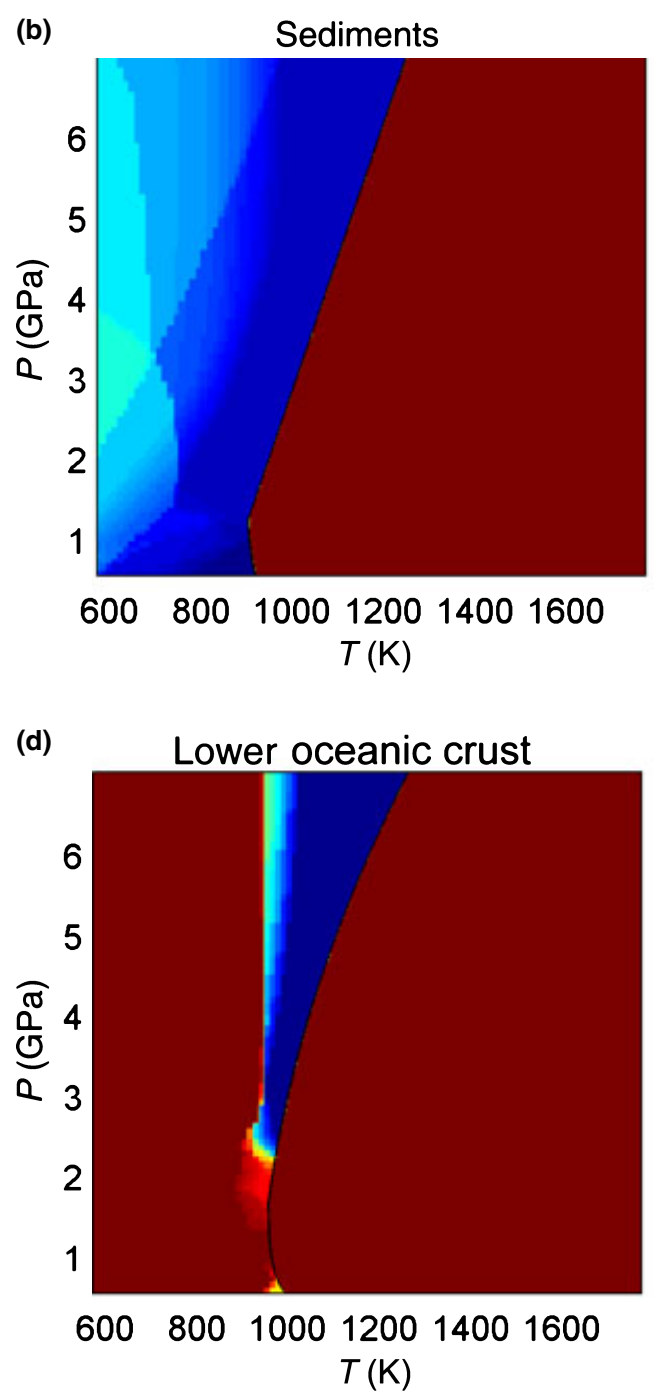

Fig. 1. (Continued).

wedge melting, melt extraction and related crustal growth in a spontaneously forming magmatic arc. This study aims to discriminate between different geodynamic regimes of subduction, which may potentially form at active continental margins depending on a local significance of fluid- and melt-related weakening.

\section{NUMERICAL MODEL DESCRIPTION}

\section{Model design}

The 2D numerical model is similar to the one explored by Sizova et al. (2010) and simulates the processes of forced subduction of an oceanic plate beneath a continental plate. It starts with the initiation of subduction and spans a period of $c$. $50 \mathrm{Myr}$. The size of the modelled area is $200 \mathrm{~km}$ in depth and $4000 \mathrm{~km}$ in length of which the subducting plate takes up $\sim 2500 \mathrm{~km}$ and the overriding plate $1500 \mathrm{~km}$ (Fig. 1a). The rectangular $1001 \times 101$ nodes non-uniform grid contains an area of
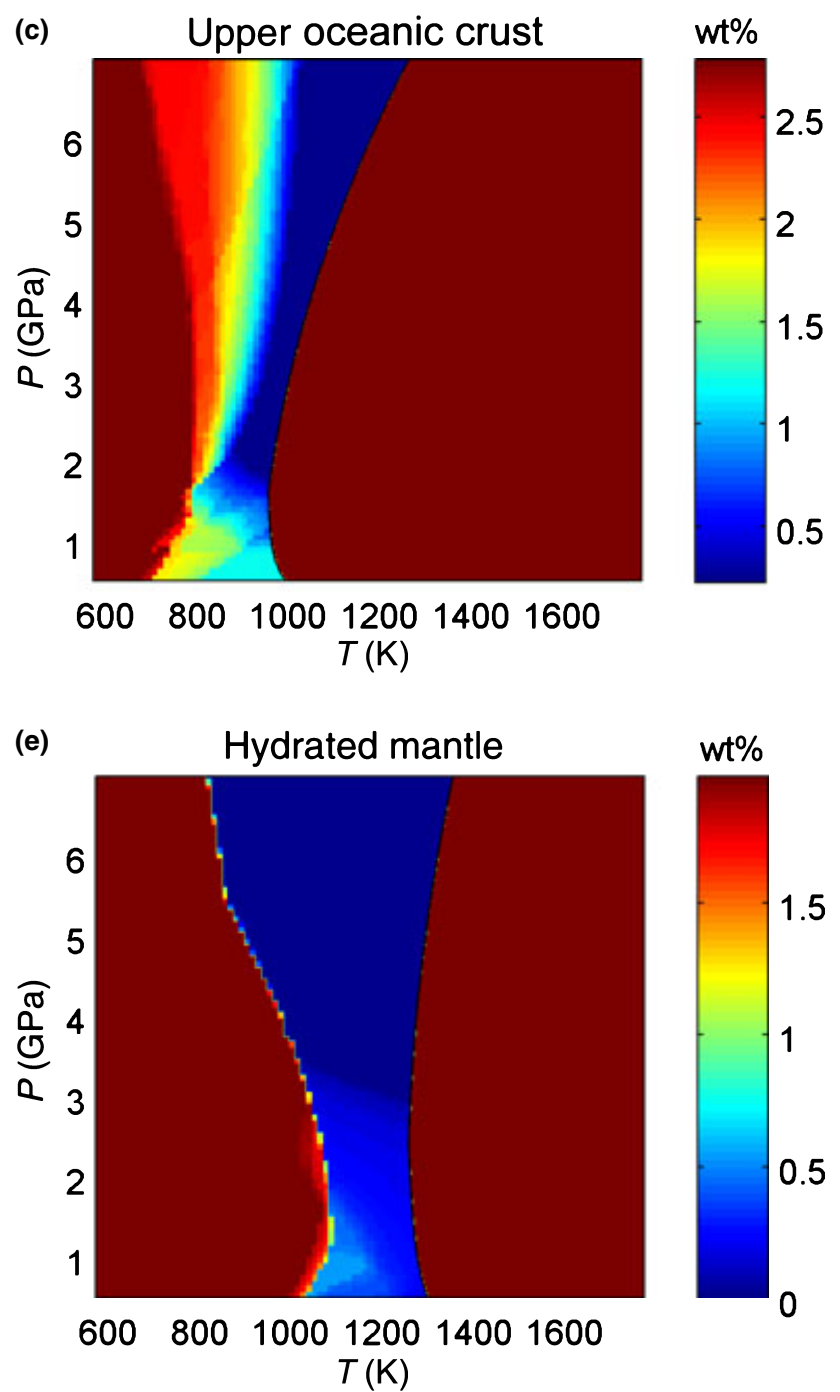

high resolution $(2 \times 2 \mathrm{~km})$ in the centre of the model, covering $1500 \mathrm{~km}$ horizontally (Fig. 1a). In the remaining part of the modelled area, the resolution is $10 \times 2 \mathrm{~km}$. In the numerical model, the oceanic crust is represented by $2 \mathrm{~km}$ of hydrothermally altered basalt, underlain by $5 \mathrm{~km}$ of gabbroic rocks. The lower $(15 \mathrm{~km})$ and upper $(15 \mathrm{~km})$ layers of the $30 \mathrm{~km}$ thick continental crust are felsic in composition. The mantle consists of anhydrous peridotite (see Table 1 for the material properties). Previous studies proposed rheological and topographic controls for subduction initiation at passive margins and indicated the importance of pre-existing fracture zones for this process (e.g. Cloetingh et al., 1982; Doin \& Henry, 2001; Regenauer-Lieb et al., 2001; Nikolaeva et al., 2010). Recent models of subduction initiation show that it might be caused by a thermal shear-heating instability (Regenauer-Lieb et al., 2001; Kaus \& Podladchikov, 2006; Crameri \& Kaus, 2010) or by a plume that impinges on the lithosphere (Ueda et al., 2008). Most of these 
models ultimately result in a weak shear zone that cuts through the lithosphere. Here, a simplified approach is taken that prescribes this initial rheologically weak shear zone (e.g. Hassani et al., 1997; Gorczyk et al., 2007; Kaus et al., 2008; Yamato et al., 2008) with wet olivine rheology and low plastic strength $[\sin (\varphi)=0.1$, where $\varphi$ is the effective internal friction angle] in the mantle lithosphere with dry olivine rheology overlain by a prism of accreted sediments at the border of the two plates (Fig. 1a). The spontaneously bending oceanic slab is driven by an internally prescribed $5 \mathrm{~cm} \mathrm{year}^{-1}$ (in all models) velocity field within the convergence condition region located inside the oceanic plate, far away from the centre of the model (Fig. 1a).

The initial temperature field in the oceanic plate is defined by an oceanic geotherm (Turcotte \& Schubert, 2002) for a 40-Myr lithospheric cooling age (in all models). Within the first $72-\mathrm{km}$ depth of the continental plate, the initial temperature field linearly increases from 0 to $1367{ }^{\circ} \mathrm{C}$; from $72-\mathrm{km}$ depth on (in the asthenospheric mantle) a gradient of $0.5^{\circ} \mathrm{C} \mathrm{km}^{-1}$. Thermal boundary conditions are as follows: $0{ }^{\circ} \mathrm{C}$ at the upper boundary, zero heat flux at the vertical boundaries and infinite-like condition at the lower boundary (Gorczyk et al., 2007).

The mechanical boundary conditions are free slip at the top and side boundaries, whereas the lower boundary is open (Gorczyk et al., 2007). Such a lower boundary condition allows for spontaneous slab penetration and bending, although it ignores the possible influence of deep $(>200 \mathrm{~km})$ slab portions on the dynamics of subduction. The top surface of the lithosphere is treated as an internal free surface by using an 8- to $12.5 \mathrm{~km}$ thick top layer with low viscosity $\left(10^{18} \mathrm{~Pa} \mathrm{~s}\right)$ and density $\left(1 \mathrm{~kg} \mathrm{~m}^{-3}\right.$ for air, $1000 \mathrm{~kg} \mathrm{~m}^{-3}$ for sea water below $y=10 \mathrm{~km}$ level). The large viscosity contrast caused by these low viscosity boundary layers minimizes shear stresses $\left(<10^{4} \mathrm{~Pa}\right)$ at the top of the lithosphere and makes it effectively a free surface (e.g. Schmeling et al., 2008). In order to account for the effects of erosion and sedimentation on the topographical evolution, the transport equation is applied at the surface (Gorczyk et al., 2007). This equation is solved at each time-step in Eulerian coordinates:

$$
\frac{\partial y_{\mathrm{es}}}{\partial t}=v_{y}-v_{x} \frac{\partial y_{\mathrm{es}}}{\partial x}-v_{\mathrm{s}}+v_{\mathrm{e}}
$$

where $y_{\mathrm{es}}$ is the vertical position of the surface as a function of the horizontal distance $x ; v_{y}$ and $v_{x}$ are the vertical and horizontals components of the material velocity vector at the surface ( $y$ is positive downward, $y=0$ at the top of the box); $v_{\mathrm{s}}$ and $v_{\mathrm{e}}$ are the sedimentation and erosion rates respectively, as given in the following relations:

$$
\begin{gathered}
v_{\mathrm{s}}=0 \mathrm{~mm} \mathrm{a}^{-1} \quad v_{\mathrm{e}}=0.3 \mathrm{~mm} \mathrm{a}^{-1} \text { for } y<9 \mathrm{~km} \\
v_{\mathrm{s}}=0.03 \mathrm{~mm} \mathrm{a}^{-1} \quad v_{\mathrm{e}}=0 \mathrm{mma}^{-1} \text { for } y>10 \mathrm{~km}
\end{gathered}
$$

In regions with steep surfaces, for example in the trench region, an increased erosion/sedimentation rate $\left(1 \mathrm{~mm} \mathrm{a}^{-1}\right)$ is used to account for additional mass transport in the regions with steep $\left(>17^{\circ}\right)$ topography slopes.

\section{Hydration process}

In the sediments and the hydrothermally altered basaltic crust, water is present as a free fluid making up to $2 \mathrm{wt} \%$ at the surface that is a rather conservative estimate (e.g. Johnson \& Pruis, 2003). The pore water content $x_{\mathrm{H}_{2} \mathrm{O}(\mathrm{P})}(\mathrm{wt} \%)$ is supposed to decrease linearly with depth, from the maximum value of $X_{\mathrm{H}_{2} \mathrm{O}(\mathrm{Po})}=$ $2 \mathrm{wt} \%$ at the surface to $0 \mathrm{wt} \%$ at $75 \mathrm{~km}$ depth:

$$
X_{\mathrm{H}_{2} \mathrm{O}_{(\mathrm{wt} \%)}}=(1-0.013 \Delta y) X_{\mathrm{H}_{2} \mathrm{O}_{(\mathrm{po})}},
$$

where $X_{\mathrm{H}_{2} \mathrm{O}(\mathrm{Po})}=2 \mathrm{wt} \%$ is the connate water content at the surface, and $\Delta y$ is depth below the surface in $\mathrm{km}$ $(0-75 \mathrm{~km})$. The release of this water also mimics the effects of low-temperature $\left(<300{ }^{\circ} \mathrm{C}\right)$ reactions that are not included in our thermodynamic database.

As the subducting slab moves downward, it is dehydrated. The timing of $\mathrm{H}_{2} \mathrm{O}$ release by dehydration reactions is determined by the model physicochemical conditions and the assumption of thermodynamic equilibrium. The stable water content (Fig. 1b-e) for each lithology (with the exception of the continental crust for which constant $1 \mathrm{wt} \%$ water content was prescribed in all models) was obtained by free energy minimization (Connolly, 2005) as a function of pressure and temperature from thermodynamic data (Gerya et al., 2006). For this purpose, phase relations were resolved on a grid with a resolution of $5^{\circ} \mathrm{C}$ and $25 \mathrm{MPa}$. The fluids propagate upward into the mantle wedge where up to $2 \mathrm{wt} \%$ of water is absorbed in agreement with seismic constraints (Bostock et al., 2002; Carlson \& Miller, 2003). The propagation of water is modelled in the form of markers: dehydration reactions lead to a release of a certain amount of water, which is stored in a newly generated water marker. Water markers move through the rocks with the following velocity

$$
\left.v_{x_{\text {(water })}}=v_{x}, \quad v_{y(\text { water })}=v_{y}-v_{y} \text { (percolation }\right) .
$$

$v_{x}$ and $v_{y}$ describe the local velocity of the mantle and $v_{y \text { (percolation) }}$ indicates the relative velocity of the upward percolation of the fluid ( $v_{y \text { (percolation) }}=$ $10 \mathrm{~cm} \mathrm{a}^{-1}$ in our experiments). Water is released by the marker as soon as it encounters a rock capable of absorbing water by hydration or melting reactions at given $P-T$ conditions and rock composition (Gorczyk et al., 2007; Nikolaeva et al., 2008; Sizova et al., 2010).

In our simplified model, mantle density changes sharply due to hydration and is different for serpentinized and serpentine-free hydrated mantle (Table 1). Density changes thus account for average effects of mantle hydration at different $P-T$ parameters (e.g. 


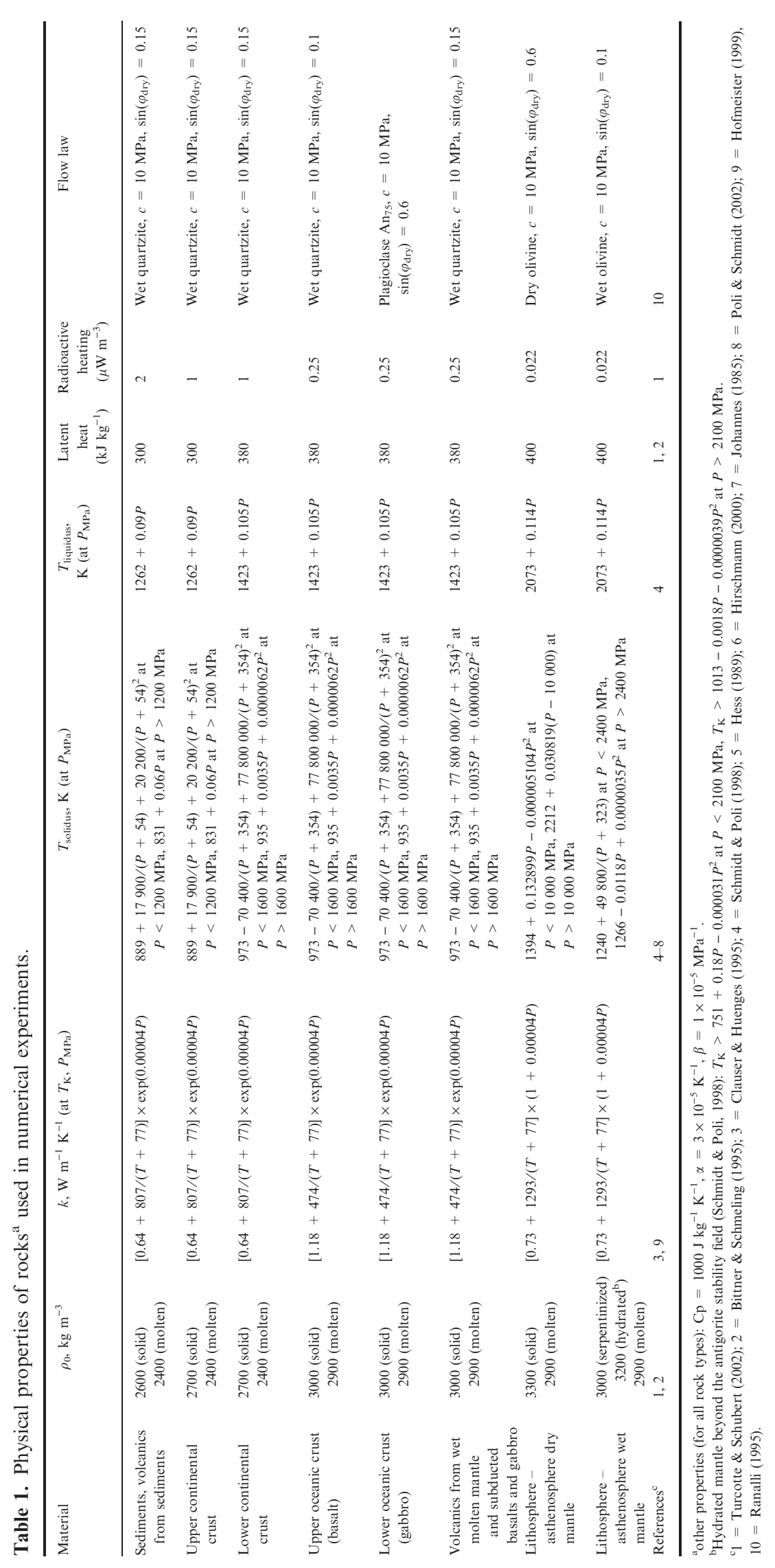


Schmidt \& Poli, 1998). Density of crustal rocks is not affected by hydration in our models.

\section{Partial melting and melt extraction processes}

Because the $\mathrm{H}_{2} \mathrm{O}$ transport model does not permit complete hydration of the peridotitic mantle, the mantle solidus is intermediate between the wet and dry peridotite solidi. To account for this behaviour, it is assumed that the degree of both hydrous and dry melting is a linear function of pressure and temperature (e.g. Gerya \& Yuen, 2003a). In this model, the standard (i.e. without melt extraction) volumetric degree of melting $M_{0}$ is,

$$
\begin{gathered}
M_{0}=0 \quad \text { when } T<T_{\text {solidus }}, \\
M_{0}=\frac{T-T_{\text {solidus }}}{T_{\text {liquidus }}-T_{\text {solidus }}} \text { when } T_{\text {solidus }}<T<T_{\text {liquidus }}, \\
M_{0}=1 \quad \text { when } T>T_{\text {liquidus }},
\end{gathered}
$$

where $T_{\text {solidus }}$ and $T_{\text {liquidus }}$ are respectively solidus temperature (wet and dry solidi are used for the hydrated and dry mantle respectively) and dry liquidus temperature at a given pressure and rock composition (Table 1). To simulate melt extraction from partially molten rocks (e.g. Nikolaeva et al., 2008; Sizova et al., 2010), a melt extraction threshold $M_{\max }=4 \%$ and a non-extractable amount of melt $M_{\min }=2 \%$ that will remain in the source are defined.

The amount of melt extracted during the evolution of each experiment is tracked by markers. The total amount of melt, $M$, for every marker takes into account the amount of previously extracted melt and is calculated as:

$$
M=M_{0}-\sum_{n} M_{\mathrm{ext}},
$$

where $\Sigma_{n} M_{\text {ext }}$ is the total melt fraction extracted during the previous $n$ extraction episodes. In our model, the rock is considered non-molten (refractory) when the extracted melt fraction is larger than the standard one (i.e. when $\Sigma_{n} M_{\text {ext }}>M_{0}$ ). In case the total amount of melt $M$ exceeds the threshold $M_{\max }$, the melt fraction $M_{\mathrm{ext}}=M-M_{\min }$ is extracted and $\Sigma_{n} M_{\text {ext }}$ is updated. The extracted melt fraction $M_{\text {ext }}$ is assumed to propagate upward to the surface much faster than the mantle rocks deform (Elliott et al., 1997; Hawkesworth et al., 1997). Hence, the instantaneous transmission of extracted melt to the surface is reasonable. At the surface, extracted melt markers create a volcanic arc and thereby retain their volume and composition. In our simplified model, melt propagation towards the surface only affects the brittle/plastic strength of rocks above the source region that is discussed below.

The effective density, $\rho_{\text {eff }}$, of partially molten rocks is calculated from

$$
\rho_{\text {eff }}=\rho_{\text {solid }}\left(1-M+M \frac{\rho_{0 \text { molten }}}{\rho_{0 \text { solid }}}\right),
$$

where $\rho_{0 \text { solid }}$ and $\rho_{0 \text { molten }}$ are the standard densities of solid and molten rock respectively (Table 1$)$ and $\rho_{\text {solid }}$ is the density of solid rocks at given $P(\mathrm{MPa})$ and $T(\mathrm{~K})$ computed from

$$
\rho_{\text {solid }}=\rho_{0 \text { solid }} \times[1-\alpha(T-298)] \times[1+\beta(P-0.1)],
$$

where $\alpha$ and $\beta$ are thermal expansion and compressibility of rocks (Table 1). Indeed, due to the applied melt extraction, the actual density difference between solid and molten rocks is rather small in our models.

\section{Rheological model}

The effective creep viscosities of rocks are represented as a function of temperature and stress by experimentally determined flow laws (Table 1). The viscosity for dislocation creep is defined (Ranalli, 1995) as follows,

$$
\eta_{\text {creep }}=\left(\dot{\varepsilon}_{\mathrm{II}}\right)^{(1-n) / n} /\left(A_{\mathrm{D}}\right)^{1 / n} \exp (E / n R T),
$$

$\dot{\varepsilon}_{\mathrm{II}}=\left(1 / 2 \dot{\varepsilon}_{i j} \dot{\varepsilon}_{i j}\right)^{1 / 2}$ is the second invariant of the strain rate tensor. $A_{\mathrm{D}}$ (pre-exponential factor), $E$ (activation energy) and $n$ (creep exponent) are experimentally determined flow law parameters and $R$ is the gas constant.

In our model, both fluid and melt propagation affect the rheology of rocks. This is implemented by using the Mohr-Coulomb yield criterion that limits the creep viscosity, altogether yielding an effective visco-plastic rheology

$$
\begin{gathered}
\eta_{\text {creep }} \leq \frac{\sigma_{\text {yield }}}{2 \dot{\varepsilon}_{\text {II }}}, \\
\sigma_{\text {yield }}=\mathrm{c}+P \sin (\varphi), \\
\sin (\varphi)=\sin \left(\varphi_{\text {dry }}\right) \lambda_{\text {fluid }}, \\
\lambda_{\text {fluid }}=1-\frac{P_{\text {fluid }}}{P_{\text {solid }}},
\end{gathered}
$$

Thus, the local plastic strength of a rock depends on the mean stress of the solids, $P_{\text {solid }}=P$ (dynamic pressure), the cohesion, $c$, which is the strength at $P=0$, and on the effective internal friction angle, $\varphi$, which is calculated from the friction angle of dry rocks, $\varphi_{\text {dry }}$ [for values of $c$ and $\sin \left(\varphi_{\text {dry }}\right)$, see Table 1], and the pore fluid pressure factor $\lambda_{\text {fluid. }}$. This prescribed fluid pressure factor is interpreted as $\lambda_{\text {fluid }}=1-$ $P_{\text {fluid }} / P_{\text {solid; }}$; the pore fluid pressure $P_{\text {fluid }}$ reduces the yield strength $\sigma_{\text {yield }}$ of fluid-containing porous or fractured rock. In dry rocks, $\lambda_{\text {fluid }}$ is thus equal to one. A hydrostatic gradient $\left(\lambda_{\text {fluid }}=0.6\right)$ is generally accepted for the porous fluid in the upper crust (Sibson, 
1990). As follows from studies of deep wells (e.g., Sibson, 1990), at great depths relevant for fluid release in subduction zones $(10-300 \mathrm{~km})$, pressure within a free porous fluid may approach lithostatic values and, consequently, $\lambda_{\text {fluid }}$ can be close to zero (see also discussion by Faccenda et al., 2009). Thus, the plastic strength of rocks in subduction zones is strongly dependent on the presence or absence of pore fluids and the values of $\lambda_{\text {fluid }}$ in fluid-bearing rocks can be strongly variable. Consequently, $\lambda_{\text {fluid }}=1$ is used for dry rocks and $\lambda_{\text {fluid }}$ is specified for fluid-bearing rocks as one of the model parameters. It is also important to mention that the presence of porous fluid in rocks is indicated locally at each time step by moving water markers.

The weakening effect of ascending melts is included in a similar manner. During a melt extraction episode, the yield strength $\sigma_{\text {yield }}$ of rock in the column between the source of the melt and the surface is decreased according to a prescribed melt pressure factor $\lambda_{\text {melt }}=1-P_{\text {melt }} / P_{\text {solid }}$.

Hydration also affects the ductile rheology of the mantle: a weaker wet olivine flow law is used for the hydrated/serpentinized mantle regions compared with a stronger dry olivine flow law in the dry mantle (Table 1). As a first approximation, a sharp transition between dry and wet mantle rheology is used that does not take into account the precise water content in the hydrated mantle. It is also assumed that intense hydration of crustal rocks occurs during subduction and therefore a relatively weak wet quartzite flow law and friction angle for all crustal rocks with the exception of the lower (gabbroic) oceanic crust (Table 1) is used.

According to our rheological model, the major parameters that affect the effective viscosities of rocks at relatively cold temperatures are weakening effects due to fluids and melts. On the other hand, temperature- and stress-dependences of viscosity are dominant rheological factors for hot rocks. Values of $10^{17}$ and $10^{25} \mathrm{~Pa}$ s are the lower and upper cut-off values for the viscosities of all types of rocks used in our numerical experiments.

\section{Computational strategy}

The momentum, continuity, and heat conservation equations (Boussinesq approximation) for the 2D visco-plastic flow are solved using the I2VIS code (Gerya \& Yuen, 2003b) based on conservative finite differences and a non-diffusive marker-in-cell technique. The common velocity field advects the temperature field as well as chemical components. In order to observe the temporal evolution of these two fields, the marker-in-cell technique is used over a fully staggered grid in Eulerian configuration. For interpolation of various parameters (density, viscosity, etc.) between markers and nodes distance-dependent bilinear arithmetic averaging rule (Gerya \& Yuen, 2003b) is used according to which markers located closer to a node have higher statistical weights. According to this method, effective physical properties of rock melanges are averaged locally from individual rock markers.

\section{RESULTS}

Systematic testing of geodynamic consequences of variable weakening effects by fluids and melts is performed. For this purpose, the two parameters $\lambda_{\text {fluid }}$ and $\lambda_{\text {melt }}$ were varied independently in a series of 30 experiments that are shown in Fig. $2\left(\lambda_{\text {melt }}=0.0\right.$, $0.001,0.01,0.1,1.0$ and $\lambda_{\text {fluid }}=0.0,0.001,0.01,0.1$, $0.3,1.0)$. Results of these experiments suggest that the geodynamic regime of subduction is strongly dependent on variations in $\lambda_{\text {fluid }}$ and $\lambda_{\text {melt }}$, which influence the mode of subduction (retreating, stable or advancing), accretion wedge development (subduction accretion/erosion processes), backarc spreading centre development, and appearance and geometry of thermal-chemical plumes (Gerya \& Yuen, 2003a) in the mantle wedge. Aqueous fluids mainly affect the forearc region. Strong fluid-related weakening $\left(\lambda_{\text {fluid }}<0.01\right)$ promotes plates decoupling and reduces subduction

(a)

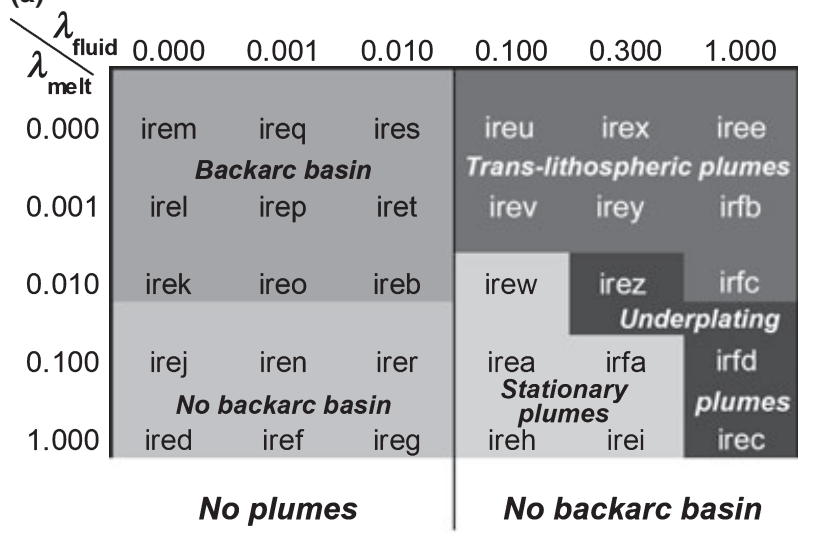

(b)

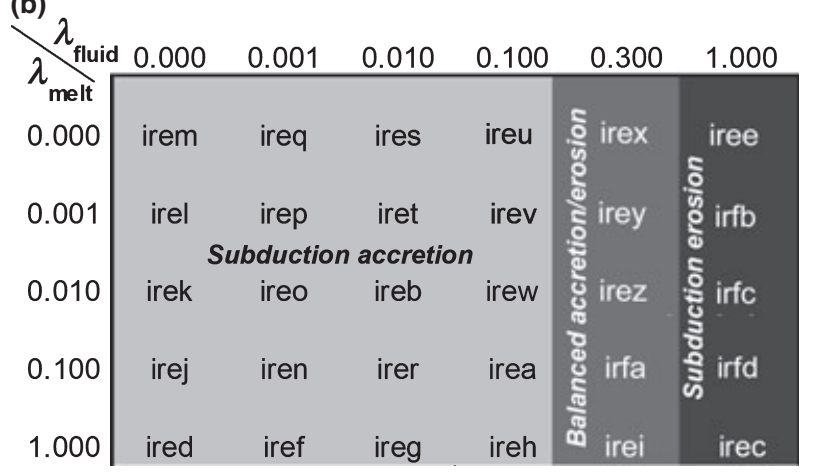

Fig. 2. Area diagram showing the explored range of variation of fluid- $\left(\lambda_{\text {fluid }}\right)$ and melt-related $\left(\lambda_{\text {melt }}\right)$ weakening effects (smaller values of $\lambda_{\text {fluid }}$ and $\lambda_{\text {melt }}$ correspond to weakening). (a) Classification of models in terms of backarc basin and sedimentary plumes development. (b) Classification of models in terms of subduction accretion and erosion. 
drag. In contrast, reduced weakening by fluids $\left(\lambda_{\text {fluid }} \geq 0.1\right)$ results in stronger plate coupling and produces advancing collision-like subduction with enhanced subduction erosion. On the other hand, melts rheologically weaken the lithosphere below the arc and thus control overriding plate extension processes.

The following five geodynamic regimes of subduction are identified in our experiments: (i) stable subduction with no backarc spreading centre and without plumes in the mantle wedge; (ii) retreating subduction with a focused backarc spreading centre and without plumes; (iii) retreating subduction with distributed intra-arc extension and trans-lithospheric sedimentary plumes; (iv) advancing subduction with underplating (laterally extending) sub-lithospheric plumes; and (v) stable to advancing subduction with stationary (laterally limited) sub-lithospheric plumes. Representative models for different subduction regimes shown in Fig. 2 are discussed below. The results of all models should be seen as relative to the chosen values for applied convergence velocity $(5 \mathrm{~cm})$ and slab age (40 Myr).

\section{Stable subduction without backarc spreading centre and sedimentary plumes}

In this study, the stable subduction regime (Figs $3 \&$ 4a) evolves in experiments with $\lambda_{\text {fluid }}<0.1$ and $\lambda_{\text {melt }} \geq 0.1$ (Fig. 2), and is characterized by neither notable extension nor shortening of the overriding plate. Due to the large weakening effect by fluids (small $\lambda_{\text {fluid }}$ ), the weakened sediments stack up at the surface above the trench and form a pronounced accretion prism with a forearc basin (Figs 3d \& 4a). The overriding plate is progressively hydrated by fluids derived from the slab, which results in the formation of a serpentinized wedge-like channel at the plate interface where subducted oceanic crust and sediments intermix with mantle hydration products to create tectonic rock mélanges (Fig. 3d). A hydrated layer is present on top of the slab at asthenospheric depths which is fuelled by subduction of serpentinite mélanges as well as by deep dehydration of the slab. Partial melting of this hydrated layer creates a pronounced source for melt extraction on top of the slab, which controls gradual growth of the volcanic sequence at the surface of the arc (Figs $3 d \& 4 a$ ). Volcanic rocks are mainly represented by melting products of hydrated mantle with minor contribution of melts from basaltic crust and sediments that construct the tectonic mélanges subducted and molten on top of the slab.

The accretion wedge in model iren (stable subduction) is composed of three parts (Figs 3d \& 14a): a 'plug' in the retro-wedge next to the margin of the continental plate, which is separated from the prowedge by a retro-thrust. In the pro-wedge, material is accreted in the form of stacked nappes. A weak layer, consisting of highly deformed material, is located at the base of the wedge along which sediments are transported into the subduction zone and are partly subducted (basal erosion; Gutscher et al., 1998; Beaumont et al., 1999; Ellis et al., 1999; Selzer et al., 2008). In Fig. 3, the growth of the accretion wedge is shown. After c. $20 \mathrm{Myr}$, the movement of the oceanic plate has led to stacking of sediments at the front of the young accretion wedge (Fig. 3b). In addition, a plug has formed: this material next to the continental crust forms a prism rather than being stacked in nappes. Part of the material of the plug is uplifted along the continental crust during the million year period since the sediments were pushed towards the continental plate. This leads to a steepening of the angle between sediments and continental crust (Fig. 3c). The left part of the plug (next to the nappes) is dragged down into the subduction zone during subduction. In this manner, a depression at the surface evolves and creates a forearc basin ('piggyback basin') (Figs 3d \& 4a). The frontal accretion continues and leads to a long, flat accretion wedge (Figs $3 d \& 14 a)$. At the base of the nappes, sediments become highly deformed; it is the location where the weakening effect of fluids is most important. Part of the material of this basal layer is subducted (basal erosion). Thus, subduction erosion consumes material from the base of the wedge as well as from the plug.

\section{Retreating subduction with focused backarc spreading centre}

A backarc spreading centre associated with the development of a new oceanic plate forms in cases with strong weakening effects from both fluids and melts ( $\lambda_{\text {fluid }} \leq 0.01$ and $\lambda_{\text {melt }} \leq 0.01$ ), implying that both sufficient plate decoupling and weakening of the continental lithosphere below the arc are necessary to allow for retreating subduction associated with spreading in the backarc region. Figure 5 show the dynamics of these processes for the reference model irep with $\lambda_{\text {fluid }}=0.001$ and $\lambda_{\text {melt }}=0.001$. Characteristic viscosity, strain rate, stress and water content fields for this model are shown in Fig. 6.

As soon as the oceanic crust of the subducting slab reaches depths of $\sim 70 \mathrm{~km}$, the hydration and wet (flux) melting of the mantle wedge above the slab interface starts. This results in growth of a magmatic arc at the surface of the continental plate above the area of hydrated and partially molten mantle that starts after c. 3 Myr of subduction. The propagation of extracted subduction-related melts (cf. flux melting, Fig. 5a,b) weakens the lithospheric mantle according to the adopted low value of $\lambda_{\text {melt }}$. In addition, the new volcanic crust, consisting mainly of basalts extracted from partially molten hydrated mantle (cf. volcanics, Fig. 5a,b), leads to thinning and subsidence of the underlying continental crust associated with the extension of the mantle lithosphere (Fig. 5a,b). In a next step, the weakening of the lithosphere below the 


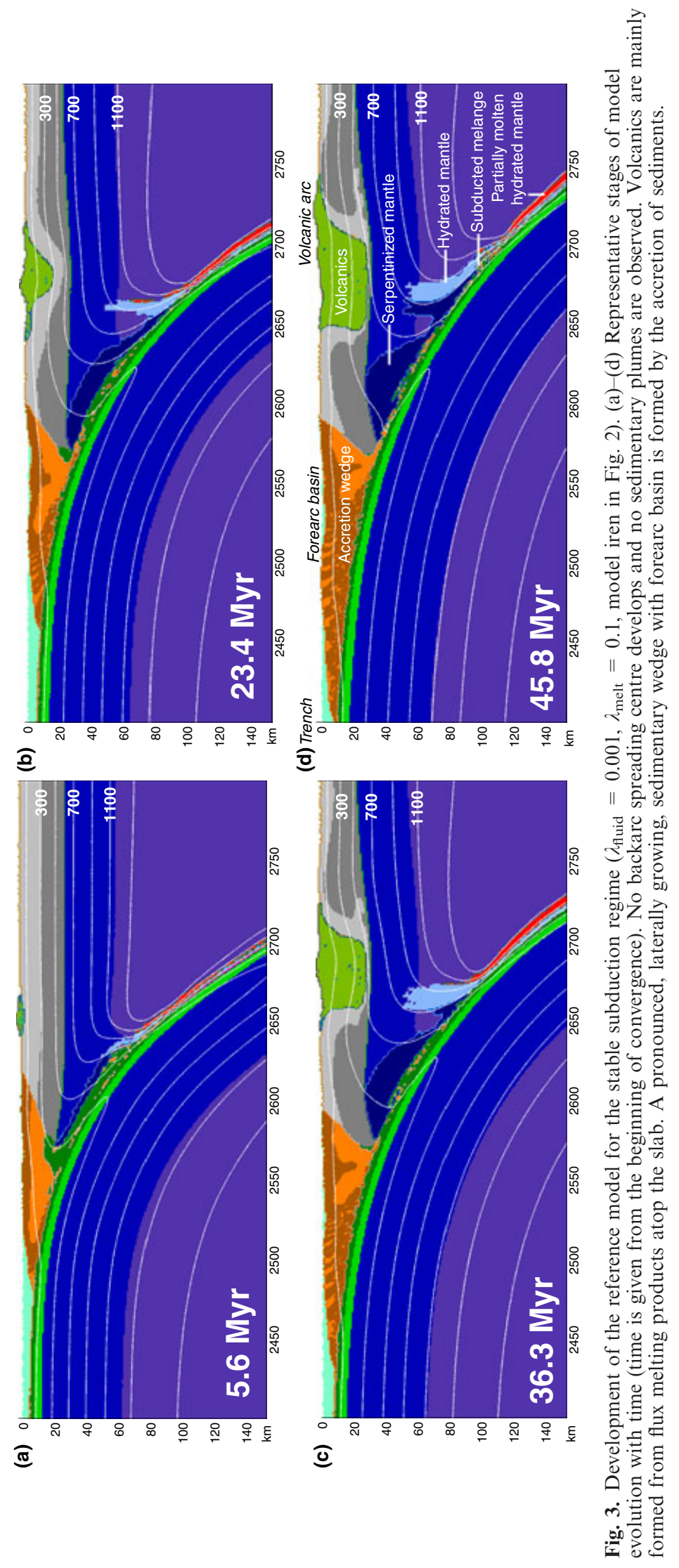



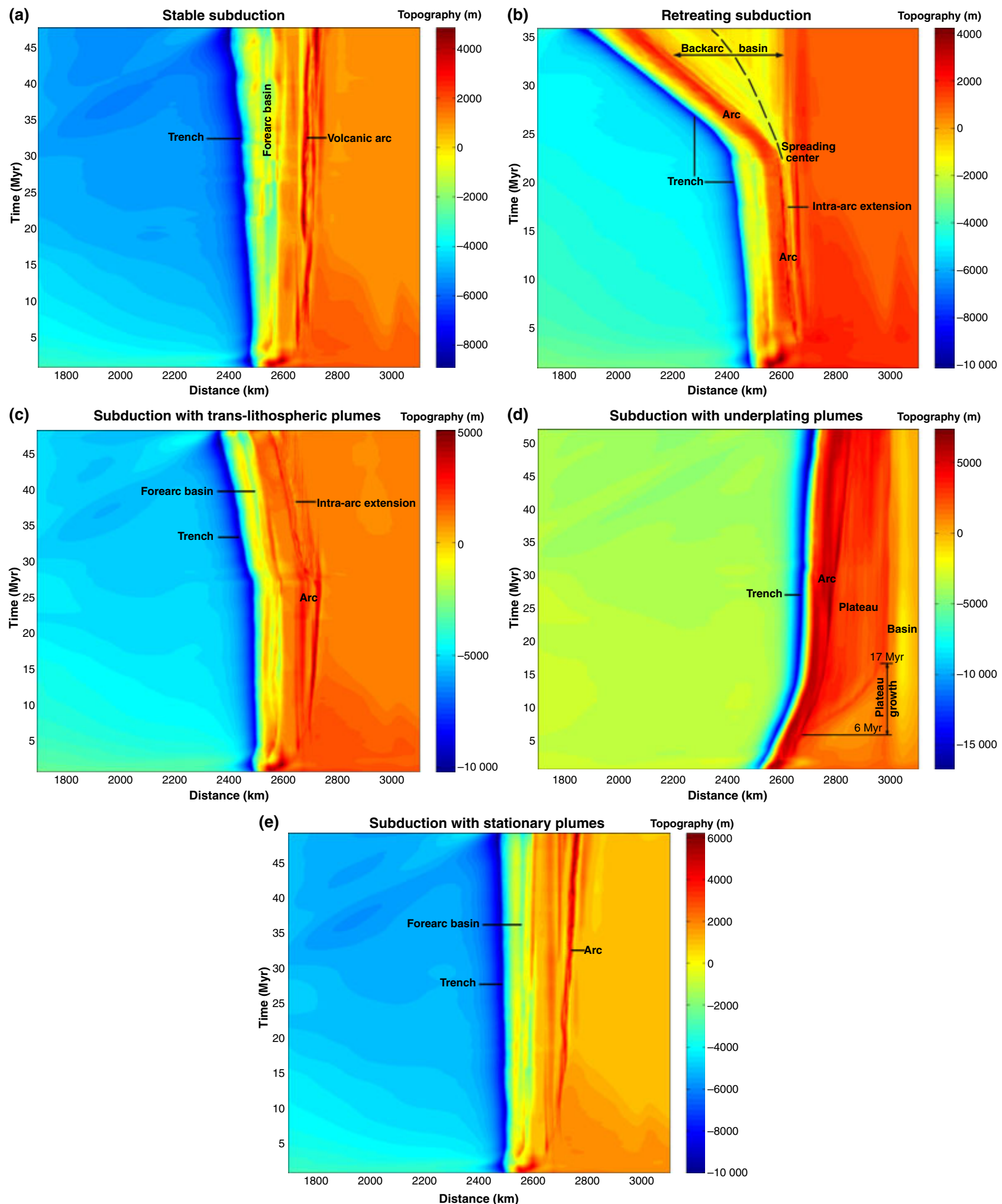

Fig. 4. Topography evolution $v$. time for five different regimes of subduction (Fig. 2a): (a) stable subduction with no backarc spreading centre and without plumes in the mantle wedge (model iren), (b) retreating subduction with the focused backarc spreading centre and without plumes (model irep), (c) retreating subduction with distributed intra-arc extension and trans-lithospheric sedimentary plumes (model irev), (d) advancing subduction with underplating (laterally extending) sub-lithospheric plumes (model irfd) and (e) advancing subduction with stationary (laterally limited) sub-lithospheric plumes (model irea). 

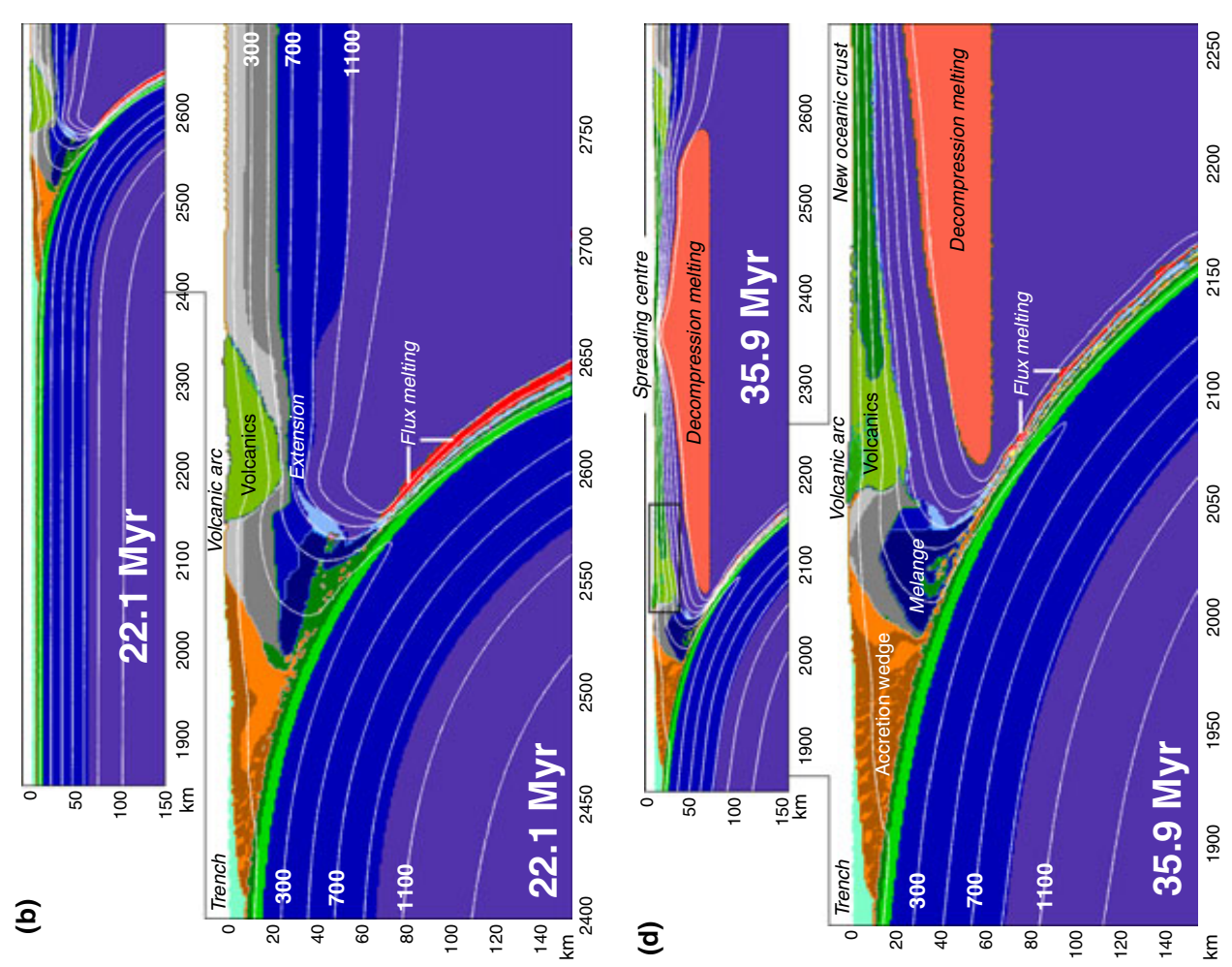

$\bar{\Xi}$ 幽

$\exists$ is

岁焉:专

ज्ञ 2 की

क

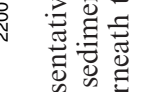

竞宅焉

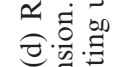

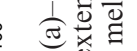

तิ

离密总

웜

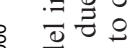

음음

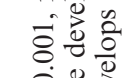

웜
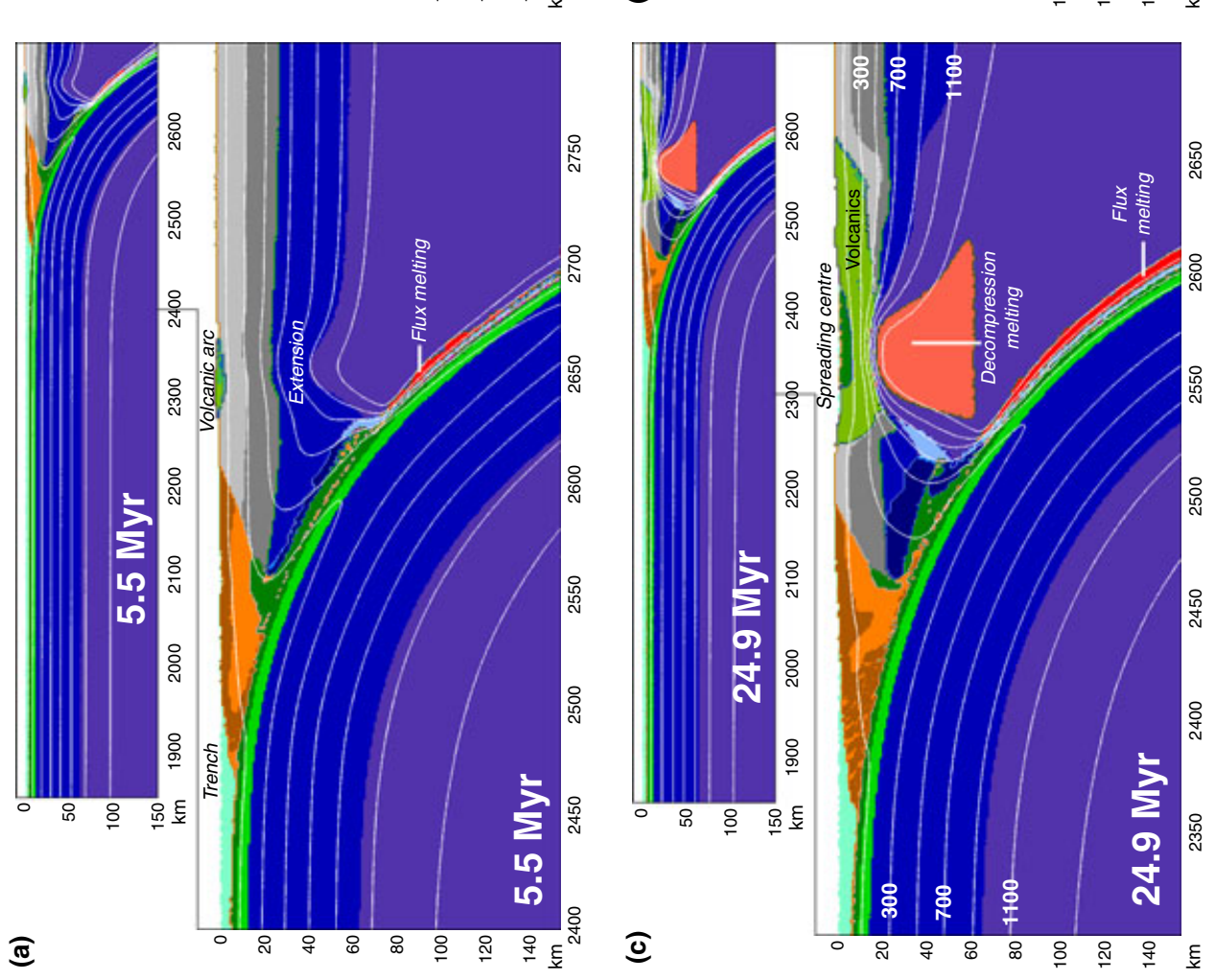

焉骂

远苛

11

急苍票

규

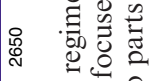

달

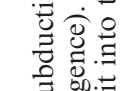

कि

吾获

気

政贯

:

ฮ

氙.

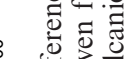

造 $\frac{0}{0} \frac{0}{0}$

包昰

를

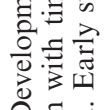

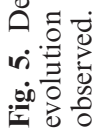



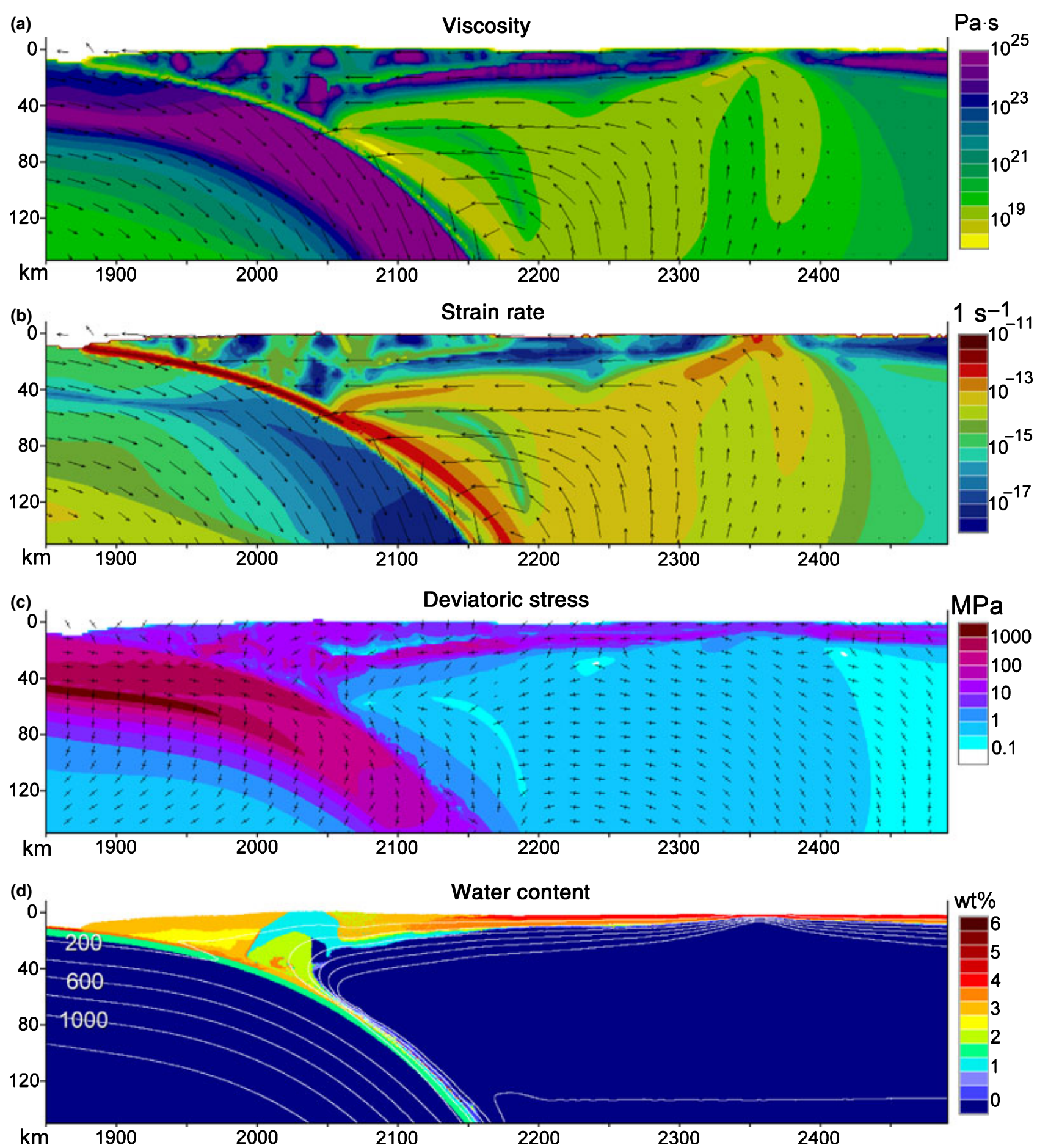

Fig. 6. Viscosity (a), strain rate (b), deviatoric stress (c) and water content (d) fields for the final stage of the reference model from Fig. 5d. Arrows in (a) and (b) show the calculated velocity field. Long and short branches of elongated crosses in (c) show orientations of largest (extension direction) and smallest (shortening direction) principal stress axes, respectively. White lines in (d) are isotherms in ${ }^{\circ} \mathrm{C}$.

arc triggers lithospheric necking and facilitates rising of hot and dry mantle asthenosphere into the neck (cf. appearance of decompression melting, Fig. 5c) as the trench is being pulled back by the retreating slab. The low coupling of the plates, due to the weak subducting slab interface (controlled by the low value of $\lambda_{\text {fluid }}$ ), and a weakened arc lithosphere (controlled by the low value of $\lambda_{\text {melt }}$ ) are both responsible for trench retreat 
and the formation of a new spreading centre in the intra-arc region (cf. spreading centre, Fig. 5c).

Due to extension in the arc area, an intra-arc spreading centre develops (which actually becomes the backarc spreading centre in the subsequent history, Fig. 4b): decompression melting of mantle material sets in after $23 \mathrm{Myr}$ of subduction (sf. Figs 5c \& 7b). The spreading centre formation accelerates the subduction rate due to trench retreat (Fig. 7c) acting as a weak gap in the overriding plate. Furthermore, MORB-like crust is generated by dry mantle decompression melting at the spreading centre (Figs $5 \mathrm{~d} \&$ 7a). Near the spreading centre (Fig. 4b), this new oceanic floor is between 2 and $4 \mathrm{~km}$ thick, whereas at the left edge where it encounters the arc, it has a maximum thickness of $10 \mathrm{~km}$ and is over- and underlain by new crust produced by wet mantle melting (flux melting, Figs $5 d \& 7 \mathrm{a}, \mathrm{b})$. On average, the new basin grows $41 \mathrm{~km} \mathrm{Myr}^{-1}$ (Fig. 4b) which equals a halfspreading rate of $2 \mathrm{~cm} \mathrm{a}^{-1}$ comparable with intermediate-spreading ridges (e.g., the Juan de Fuca Ridge: half-rate $2.5-3.3 \mathrm{~cm} \mathrm{a}^{-1}$; Turcotte \& Schubert, 2002). Above the mantle wedge closer to the slab, subductionrelated volcanics are developed (Fig. 7a) that are mainly basalts derived from wet molten mantle with a small addition of subducted crust melting products (from sediments and upper oceanic crust molten atop the slab, Fig. 7a,b).

Most of the newly formed magmatic rocks result from both wet and dry melting of mantle material, which constitute $40.9 \%$ and $56.7 \%$ respectively of the total amount of magmatic rocks after $36 \mathrm{Myr}$ of subduction (Fig. 7b). The contributions of volcanic rocks originating from subducted crust are minor: $1.7 \%$ from sediments/upper continental crust and $0.7 \%$ from oceanic crust/lower continental crust.

In the forearc region, the lithospheric mantle below the continental crust is intensely serpentinized. Serpentinization is facilitated by hydration through fluids arising from the downgoing slab and by the low temperature conditions in the 'cold nose' of the mantle wedge. The wedge-like serpentinized area composed of intermixed mantle and crustal rocks (tectonic mélange) grows progressively in the course of subduction until almost the entire forearc mantle lithosphere is hydrated (35.9 Myr, Fig. 5d).

\section{Subduction with mantle wedge plumes}

In our model, plumes composed of partially molten subducted rocks only form for relatively high values of $\lambda_{\text {fluid }} \geq 0.1$ (Fig. 2a), which correspond to cases with relatively strong plate coupling and respectively increased subduction erosion of sediments. These cases are therefore characterized by increased thickness of the subducted sedimentary layer, which is sufficiently thick to trigger development of chemically buoyant partially molten plumes atop the slab. The following types of plumes are identified: (i) trans-lithospheric (a)

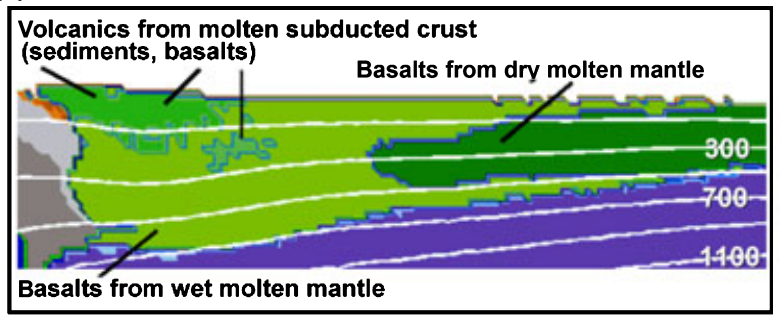

(b)
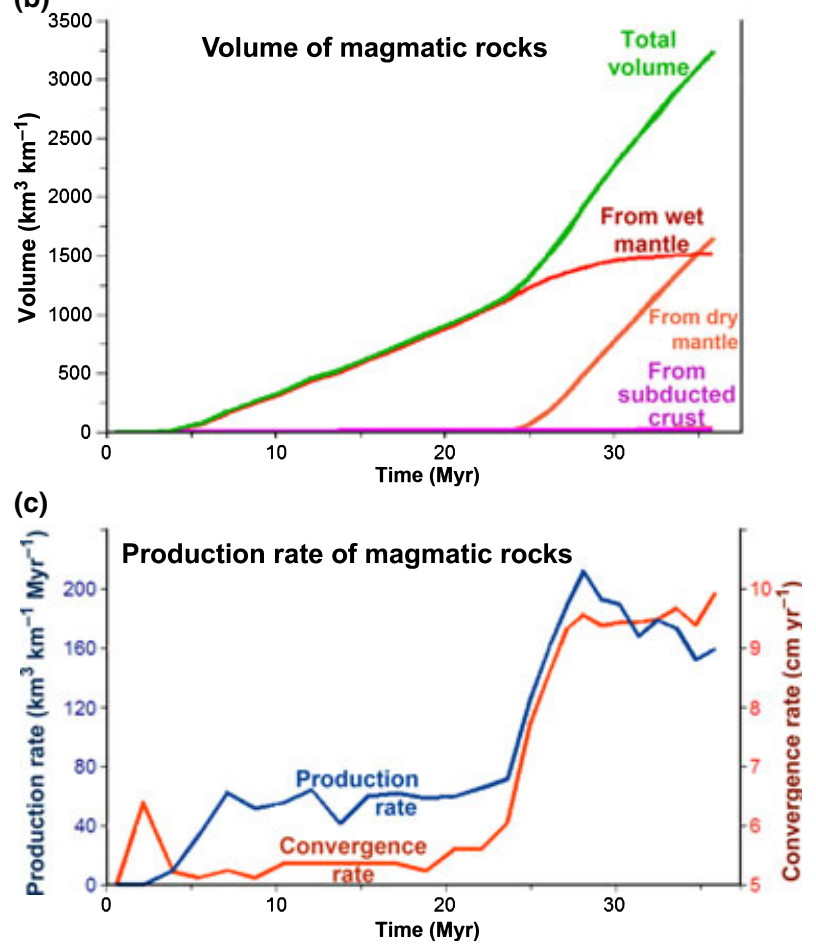

Fig. 7. (a) Lithological structure of the magmatic arc and (b)-(c) dynamics of crustal growth for the reference model of retreating subduction shown in Fig. 5. Convergence rate in (c) includes both prescribed subduction rate of the right plate and the rate of the trench retreat. Crustal growth rate and convergence rate are strongly correlated due to the rapid oceanic crust growth after opening of the backarc basin (Fig. 5c,d).

plumes that ascend and break through the continental crust (Fig. 8); (ii) extending underplating sub-lithospheric plumes (Fig. 11); and (iii) stationary laterally limited sub-lithospheric plumes that remain in the upper left mantle wedge corner above the subducting slab (Fig. 12).

\section{Subduction with ascending trans-lithospheric plumes}

Positively buoyant plumes can only penetrate into the continental lithosphere if this lithosphere is (locally) weak enough. Thus, a sufficient weakening effect by melts is required: for $\lambda_{\text {melt }} \leq 0.001$ the plumes intrude into the continental crust. Fluids affecting the forearc region also influence trans-lithospheric plume 

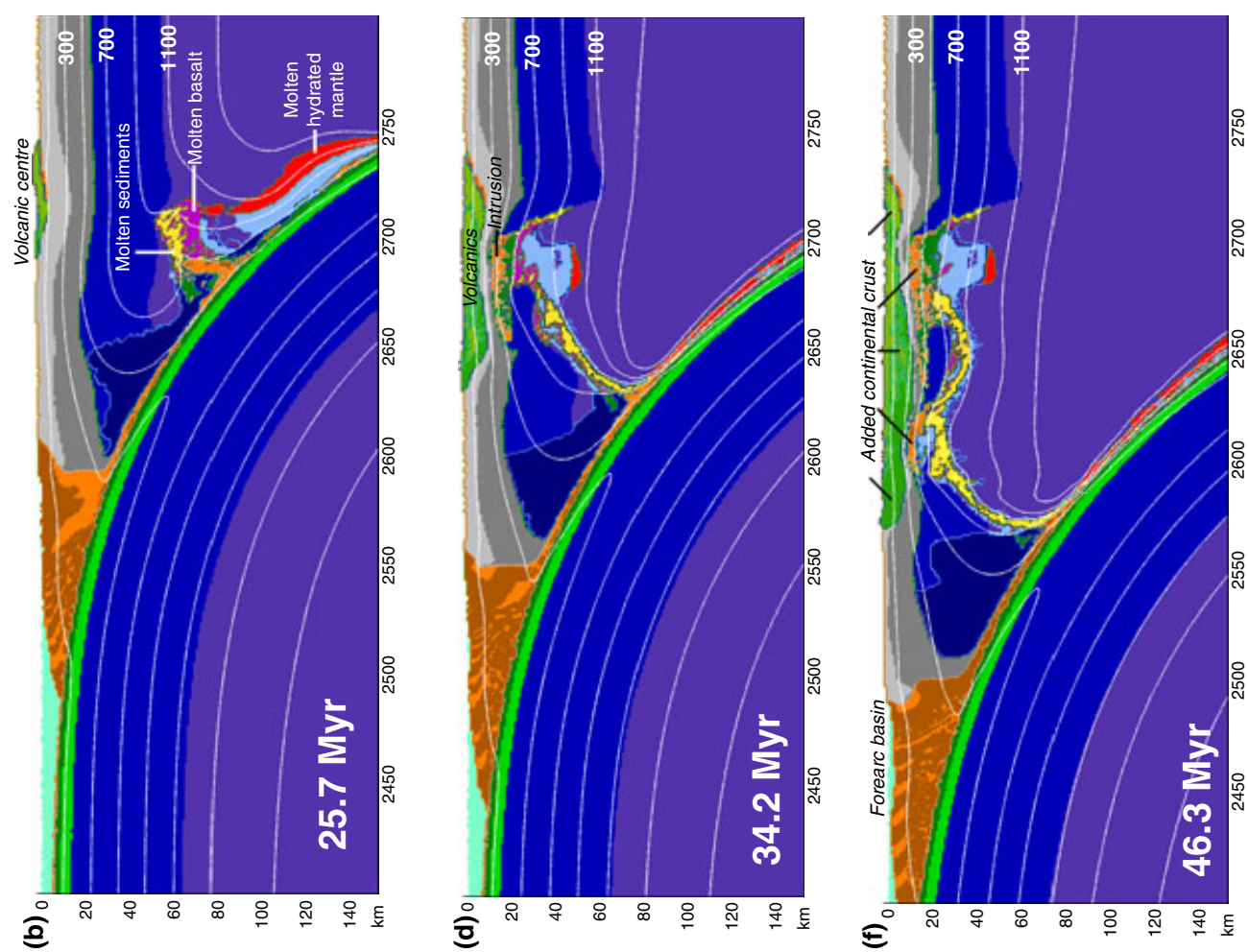

$\mathbb{0}_{0}$

फ

总:

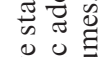

$\stackrel{\circlearrowright}{2}$

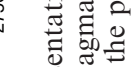

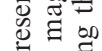

흐을

웅

ङ

तิ

ois 0 品

政.

.$\Xi$ 잉

总害势

बे

记

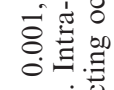
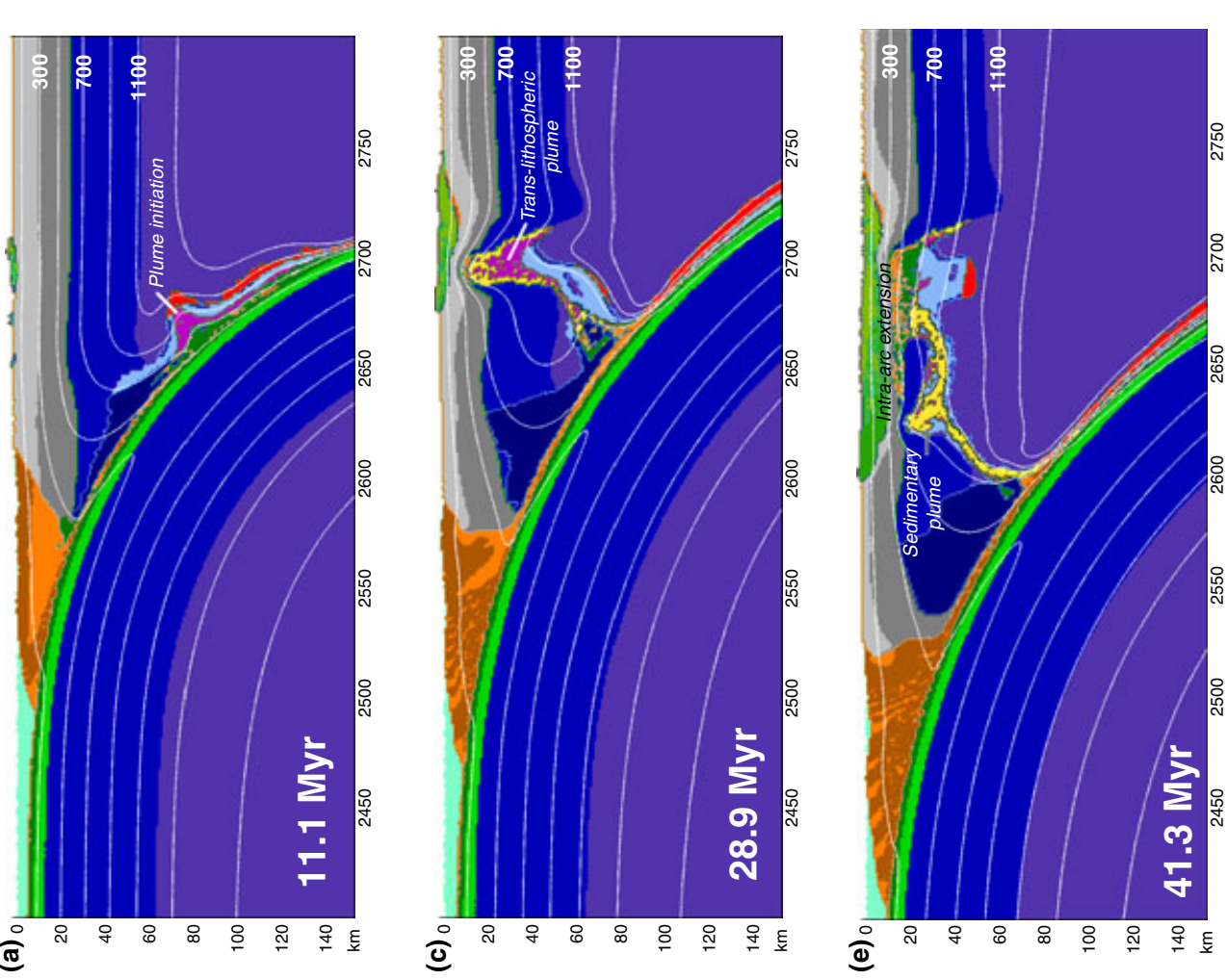

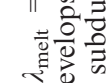

$\rightarrow$ क

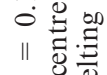

蛋骂

का

空。

는 근

흘

o

흥을

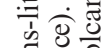

记

$\exists$

节

.

突

골

힝

웧

명

过

एँ

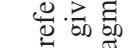

$\stackrel{0}{0} \sum^{\pi}$

递官

苛. 号

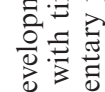

ค.

$\infty$.

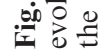


development: strong coupling (large $\lambda_{\text {fluid }}$ ) between plates produces thicker layer of sediments subducted to asthenospheric depths, which in turn creates more favourable conditions for the development of thermochemical sedimentary plumes (e.g. Currie et al., 2007). Consequently, more partially molten sediments are formed in the mantle wedge, which leads to a notable local weakening of the continental lithosphere and results in trans-lithospheric plumes at higher values of $\lambda_{\text {melt }}$ (e.g. model irfc in Fig. $2 \mathrm{a}, \lambda_{\text {fluid }}=1, \lambda_{\text {melt }}=$ $0.01)$.

The development of a trans-lithospheric plume is shown in Fig. 8. This reference model for an ascending plume has $\lambda_{\text {fluid }}=0.1$ and $\lambda_{\text {melt }}=0.001$. The plume is initially formed from the upper oceanic crust (basalts) subducted at the top of the slab (Fig. 8a, 11.1 Myr). In a next step, subducted sediments and hydrated partially molten mantle add to the growing plume and become partially molten (Fig. 8b, 25.7 Myr). The melt extracted from all molten components of the plume (basalts, sediments, hydrated mantle) starts to produce new volcanic crust at the surface (Figs $8 b \& 4 c$ ). The percolation of extracted melts is not modelled in this study, but the column of rock above the plume head is rheologically weakened (according to $\lambda_{\text {melt }}=0.001$ ) during the episodes of melt extraction. This weakening results in the formation of a weak vertical channel which allows the plume to ascend through the mantle lithosphere and intrude into the crust (Fig. 8c, $28.9 \mathrm{Myr}$ ). Due to the weak gap in the lithosphere, trench retreat and intra-arc extension take place (Fig. 4c), leading to thinning of the continental lithosphere partly compensated by magmatic addition from the plume in form of large flattened intrusions emplacing into the extending lower crust (Fig. 8d,e). Finally, the volcanic arc is underlain by batholithiclike plutons consisting of solidified restite from the partially molten and quenched plume rocks (mainly sediments and basalts, Fig. 8f, $46.3 \mathrm{Myr}$ ).

The influence of chemical buoyancy for the dynamics of trans-lithospheric plumes is investigated by conducting four additional experiments with increased density of sediments $(2700,2800,2900$ and $3000 \mathrm{~kg} \mathrm{~m}^{-3}$, Fig. 9) compared with the reference model. As a consequence of the increasing density of sediments, the ability of plumes to ascend decreases, and if plumes occur, they form at deeper positions (cf. Figs 8 \& 9a). For a sediment density of $2800 \mathrm{~kg} \mathrm{~m}^{-3}$, the plume does not intrude into the continental lithosphere (Fig. 9b) within the modelled period of time, and an even greater density $\left(2900-3000 \mathrm{~kg} \mathrm{~m}^{-3}\right)$ precludes formation of sedimentary plumes (Fig. 9c,d). Instead of detaching from the slab and ascending as a plume, heavier sediments get subducted.

Another important consequence of the increasing density of sediments is that the amount of new volcanic crust decreases significantly (Fig. 10). The decrease in magmatic activity can be explained by the absence of the chemically buoyant perturbations at the top of the upper slab surface (such as plumes, waves and domes; Gerya et al., 2004; Zhu et al., 2009), which strongly enhance melting atop the slab and respectively magmatic activity related to subduction (Gorczyk et al., 2007; Nikolaeva et al., 2008; Zhu et al., 2009). Particularly, the ascent of sedimentary plumes heats up the surface of the subducting slab: cold hydrated material leaves the slab interface together with the plume and is substituted by the hot mantle rocks coming towards the subducting slab (Fig. 8b,c). Thereby, flux melting increases and consequently, the volume of volcanic rocks in the arc is larger than in experiments without an ascending plume.

\section{Subduction with laterally extending underplating sub-lithospheric plumes}

Laterally extending plumes can be observed in experiments with increased values of both $\lambda_{\text {fluid }}$ and $\lambda_{\text {melt }}$ (Fig. 2a) where large sedimentary plumes are formed due to the significant subduction erosion promoted by a smaller amount of fluid-related weakening of the forearc $\left(\lambda_{\text {fluid }} \geq 0.3\right)$. In contrast to the previous model, these plumes cannot intrude into the crust due to the strong overriding continental mantle which is insufficiently weakened by extracted melts $\left(\lambda_{\text {melt }} \geq 0.01\right)$. Instead, these plumes grow horizontally beneath the shortening continental lithosphere (Figs $11 \& 4 d$ ).

The development of an underplating plume (reference model irfd with $\lambda_{\text {melt }}=0.1$ and $\lambda_{\text {fluid }}=1$, see Fig. 11) goes along with strong coupling of the plates that causes subduction erosion, including notable subduction of the continental crust. This induces a collision-like subduction with uplift of the continental plate and a very steep angle of the subducting plate. The lighter subducted material forms a plume and propagates under the continental lithosphere where it partially melts due to intense heat exchange with hot asthenospheric mantle (Fig. 11a,b). At this initial stage, melting and melt extraction occur along the entire length of the plume due to lateral temperature variations: the temperature in the sedimentary plume grows outward from the slab from 700 to $1050{ }^{\circ} \mathrm{C}$ within $150 \mathrm{~km}$ (Fig. 11b). Plume propagation results in a transient broadening of the magmatic arc to $\sim 150 \mathrm{~km}$ that is reflected by wide region of plumerelated volcanics formed at the surface above the plume (Fig. 11b). At the later stage, temperature along the plume stabilizes $\sim 1050$ to $1100^{\circ} \mathrm{C}$ and a notable increase in temperature (and respectively melting and melt extraction) occurs in the $30-50 \mathrm{~km}$ wide region close to the slab (Fig. 11c). The active magmatic arc narrows respectively while early plume-related volcanics are eroded from the surface (Fig. 11c). Also, at the latest stage of model development, supply of sedimentary material to the plume decreases: newly subducted sediments do not move away from the slab but circulate in the serpentinized channel (tectonic mélange) as well as in a vortex that develops in the 


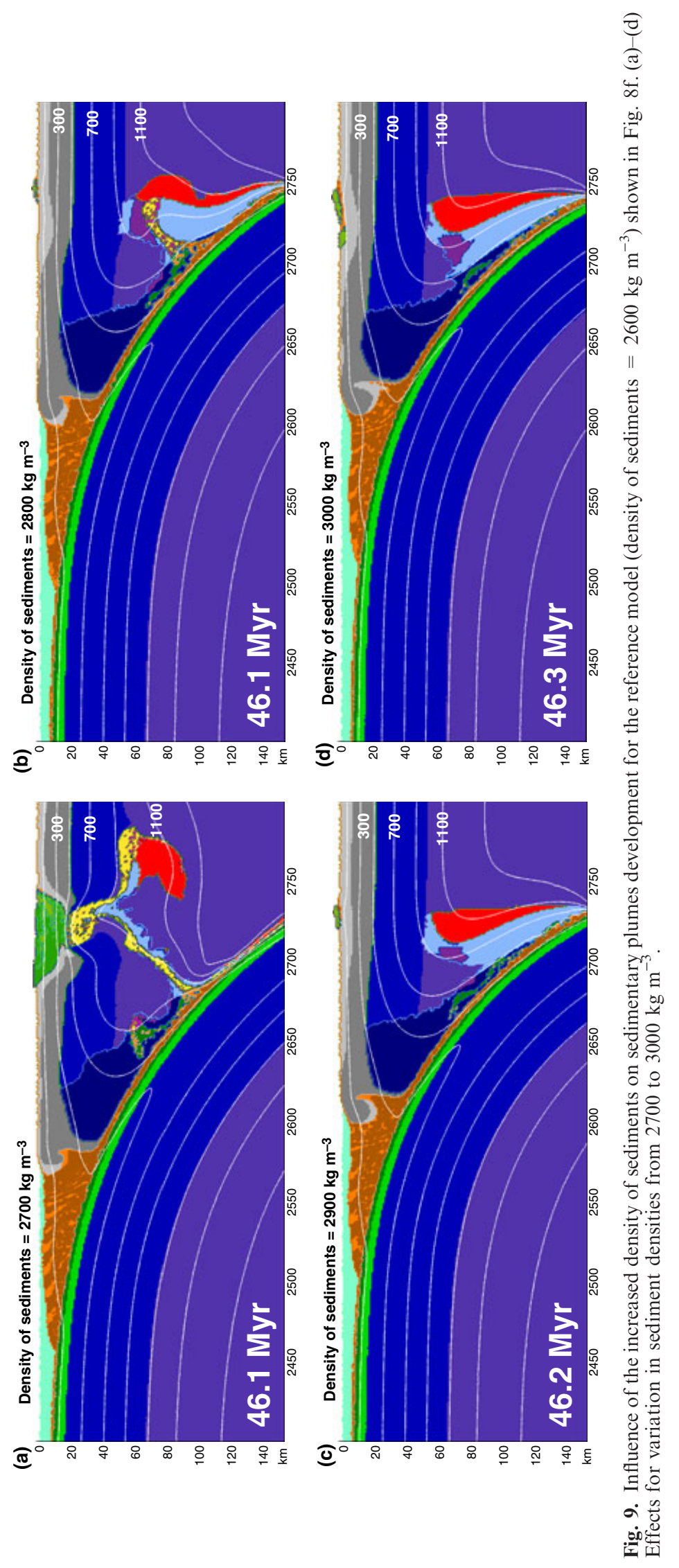




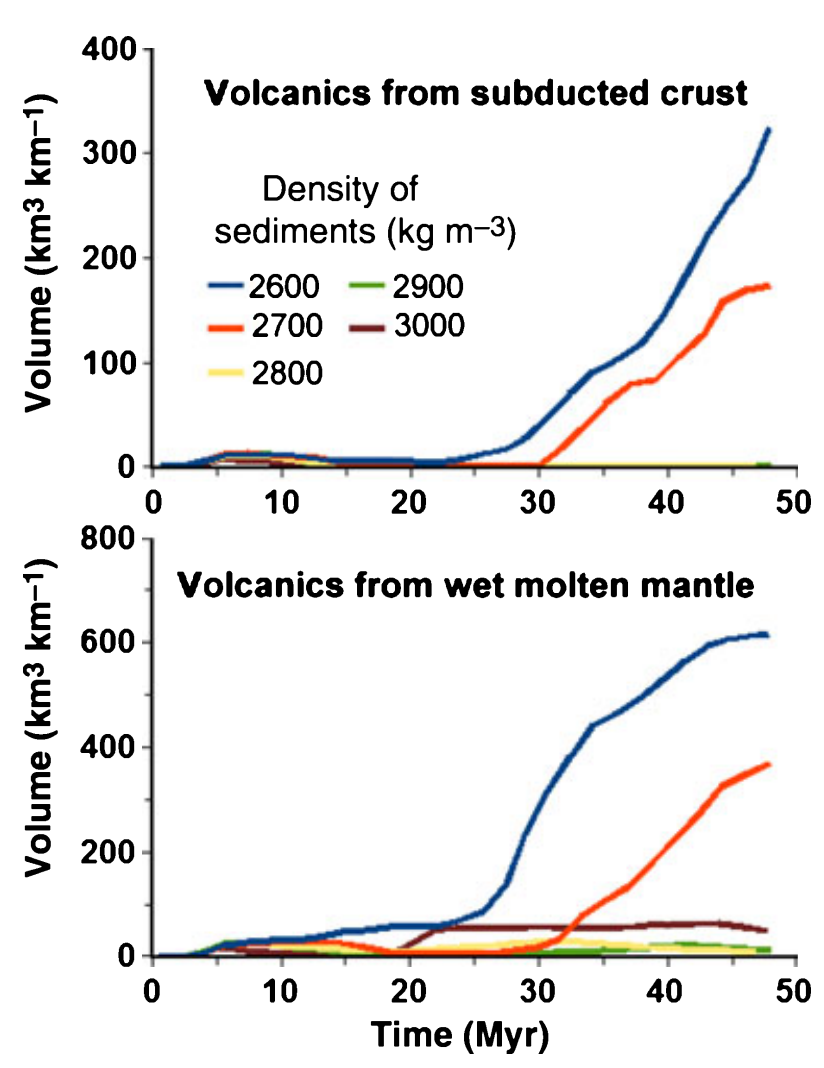

Fig. 10. Influence of density of sediments on volcanic crust growth for the models shown in Figs 8 \& 9.

bottom of the channel. After the possible amount of melt according to the $P-T$ conditions is extracted, the plume material consists of restite. The propagation of a plume beneath the continental plate leads to delamination of the continental lithosphere, which is dragged down into the asthenosphere together with some of the material of the plume (Fig. 11d).

Due to the negligible fluid-related weakening $\left(\lambda_{\text {fluid }}=1\right)$ at the interface between subducting and overriding plate, the plates are strongly mechanically coupled. In combination with melt-related weakening, this strong coupling leads to shortening of the continental plate entailing crustal thickening and uplift of a plateau (left part of the continental plate, Figs 11c \& 4d). In addition, it also results in flexure of the continental plate, which is expressed by a small basin (depression) to the right side of the plateau (right part of the continental plate, Figs $11 \mathrm{c} \& 4 d$ ). Due to the extreme plate coupling, topography in this model is also quite extreme (Fig. 4d) with heights of over $7000 \mathrm{~m}$ and a maximum depth of $-16000 \mathrm{~m}$ in the trench. In contrast, models with low coupling (such as for example $\lambda_{\text {fluid }}=0.001$, Figs $3 \& 4$ a) have a much shallower topography.

The plateau grows laterally with time (5-20 Myr) and then its width stabilizes at 250-300 km (Fig. 4d). This is clearly coupled with the advancing and underplating plume beneath the continental plate, which follows the deflection of the lithosphere caused by crustal thickening (Fig. 11b-d). The plateau uplift can be ascribed mainly to crustal thickening as well as to some contribution by plume underplating with positive buoyant sedimentary material. For the advance of the plume, the uplifted area offers a convenient place to accumulate plume material beneath the deflected lithosphere. Crustal thickening 'pushes' the plume head forwards (to the right) whereas the deflected lithosphere in front of the plume head acts as some kind of 'stopper' (Fig. 11c,d).

\section{Subduction with stationary laterally limited sub-lithospheric} plumes

Stationary plumes are quite similar to underplating ones but they do not extend horizontally for more than 30-70 km, and are not associated with strong shortening and deflection of the continental lithosphere (Figs $12 \&$ 4e). Stationary plumes occur for $0.01<\lambda_{\text {fluid }}<1$ and $\lambda_{\text {melt }}>0.001$ (Fig. 2a). These plumes remain below the subducting plate in the upper left corner of the mantle wedge (Fig. 12d). The length of the plume is mainly defined by the intensity of subduction erosion of sediments and increases with decreasing fluid-related weakening along the plate interface. Models with less fluid-related weakening $\left(\lambda_{\text {fluid }}=0.3, \quad\right.$ Fig. $\left.2 \mathrm{a}\right)$ are rather transitional to underplating plume regimes, with the difference that horizontal extent of the plumes (up to $70 \mathrm{~km}$ ) is smaller and crustal thickening is less pronounced. On the other hand, models with lower $\lambda_{\text {fluid }}=0.1$ are transitional to ordinary subduction without a backarc spreading centre and with a large accretion prism that is not eroded due to the lowered coupling between plates (cf. Figs 3, 4a,e \& 12).

\section{DISCUSSION}

\section{Crust growth rates}

Crustal growth rates in our experiments are strongly variable in time and depend on the regime of subduction (Fig. 13a). Rates of crust accumulation in models without backarc spreading centre formation typically vary from 0 to $60 \mathrm{~km}^{3} \mathrm{~km}^{-1} \mathrm{Myr}^{-1}$ where the main magmatic addition is given by flux melting products (hydrated mantle and subducted crust). In contrast, in the case of backarc spreading centre formation, crustal growth rates may reach $200 \mathrm{~km}^{3} \mathrm{~km}^{-1} \mathrm{Myr}^{-1}$ (Figs 7c $\& 13 \mathrm{~b}$ ) due to a strong contribution from decompression melting of dry mantle that creates new oceanic crust around the backarc spreading centre (Figs 5d \& 7a).

Our crustal growth rate estimates are comparable with nature. Reymer \& Schubert (1984) estimated rates of crustal generation as $20-40 \mathrm{~km}^{3} \mathrm{~km}^{-1} \mathrm{Myr}^{-1}$ for the western Pacific region based on the total arc crust volume divided by the oldest known igneous age. More 


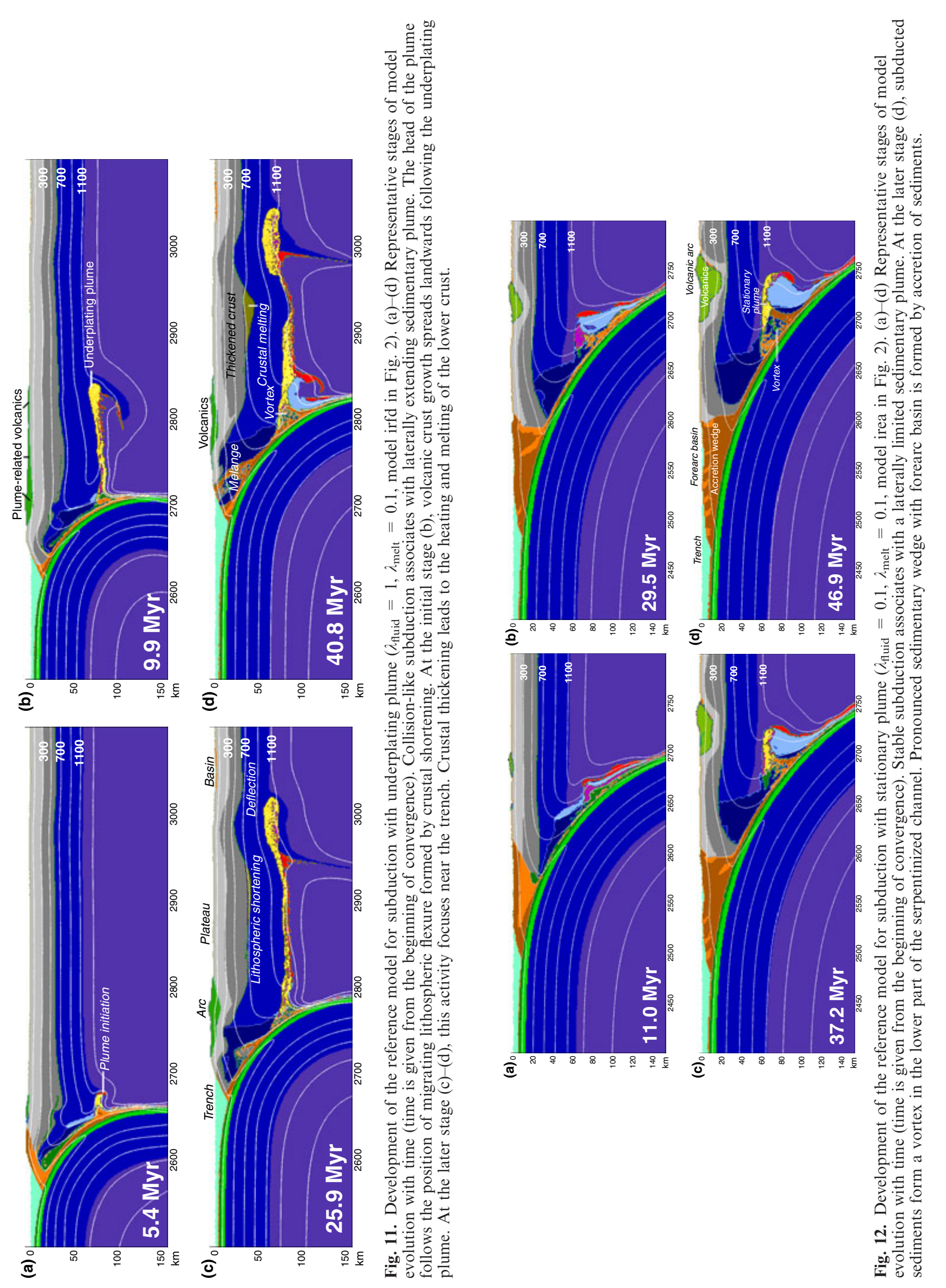


recent estimates for the same area by Taira et al. (1998, Izu-Bonin island arc), Holbrook et al. (1999, Aleutian island arc) and Dimalanta et al. (2002, Tonga, New Hebrides, Marianas, Southern and Northern IzuBonin, Aleutian island arcs) are somewhat higher, $40-95 \mathrm{~km}^{3} \mathrm{~km}^{-1} \mathrm{Myr}^{-1}$, and are much higher, 120 $180 \mathrm{~km}^{3} \mathrm{~km}^{-1} \mathrm{Myr}^{-1}$, according to the work of Stern \& Bloomer (1992, early stage of IBM development). In particular, the arc magmatic addition rate of the New Hebrides arc varies between 87 and $95 \mathrm{~km}^{3} \mathrm{~km}^{-1} \mathrm{Myr}^{-1}$ according to Dimalanta et al. (2002). They also gave values for addition rates of other island arcs, all of which vary between 30 and $70 \mathrm{~km}^{3} \mathrm{~km}^{-1} \mathrm{Myr}^{-1}$. These values are average rates of crust production, calculated by dividing the estimated total volume of produced crust by the time in which it was produced and by the length of the arc.

If the average crust production rate is calculated for our reference model with backarc spreading (Figs 5 \& 7), a value of $97.5 \mathrm{~km}^{3} \mathrm{~km}^{-1} \mathrm{Myr}^{-1}$ is obtained for the total amount of new crust. This value, however, also includes decompression melting products (MORB-type crust) formed in the new spreading centre (Fig. 5d). Thus, the crustal addition rate is rather overestimated as the production of new oceanic floor is typically not included in calculations of crust production rates of natural volcanic arcs. If the crust produced by dry melting is fully excluded, an average crust production rate of $45.9 \mathrm{~km}^{3} \mathrm{~km}^{-1} \mathrm{Myr}^{-1}$ is obtained in our reference model with backarc spreading. Indeed, some part of the dry decompression melting in nature also contributes to the formation of magmatic arcs close to the backarc region where the amount of water in the source region is considerably smaller (e.g. Kelley et al., 2006). In our model, this region is expressed by the inter-layered flux melting and decompression melting products (Fig. 7a). Therefore, the actual value of crustal growth rate in our models is between two marginal estimates of 97.5 and $45.9 \mathrm{~km}^{3} \mathrm{~km}^{-1} \mathrm{Myr}^{-1}$ and is thus quite comparable to nature.

\section{Subduction accretion and erosion}

During subduction, sediments often accumulate in the trench region to build up an accretion wedge (Fig. 3d). On the other hand, a significant amount of sediments can be subducted that, in an extreme case, leads to the complete subduction erosion of a sedimentary wedge (Fig. 11d). In our models, the amount of subducted and eroded sediments is strongly dependent on fluid-related weakening of the forearc (i.e. on $\lambda_{\text {fluid }}$ ). Smaller values of $\lambda_{\text {fluid }}$ (i.e. larger weakening effect by fluids) thus results in weaker sediments that tend to decouple from the plate, stack up and remain at the surface rather than subduct with the slab (i.e. lowered subduction erosion, Fig. 3). In contrast, increased values of $\lambda_{\text {fluid }}$ favour higher rheological strength of sediments that enhances subduction erosion and reduces the size of the accretion wedge (Fig. 11). In the extreme case of maximum $\lambda_{\text {fluid }}=1$, sediments are fully coupled to the slab and are entirely subducted.

In general, three regimes of sedimentary wedge dynamics are characteristics (Figs $2 \mathrm{~b} \&$ 14a-d): (i) subduction accretion regime $\left(\lambda_{\text {fluid }}<0.3\right.$, Fig. 14a,b) sediments accretion dominates and a large accretion wedge is built with time; (ii) balanced accretion/erosion regime $\left(\lambda_{\text {fluid }} \approx 0.3\right.$, Fig. $\left.14 \mathrm{c}\right)$ - accretion and erosion of sediments tend to compensate each other and accretion wedge size remains stable; and (iii) subduction erosion regime $\left(\lambda_{\text {fluid }}>0.3\right.$, Fig. $\left.14 \mathrm{~d}\right)$ - sediments are eroded by subducting slab and sedimentary wedge gradually disappears. Figure $14 a-d$ shows the changes in subduction accretion/erosion with increasing $\lambda_{\text {fluid }}$. Due to the fact that sediments become rheologically stronger, subduction erosion increases until even continental crust is eroded. The plug becomes more and more subducted until the angle between sediments and continental crust is reversed (cf. Fig. 14a,b) and another weak zone at this interface is established along which continental crust is subducted (Fig. 14c). Overall, the accretion prism is shorter and steeper without forarc basin and plug (Fig. 14c), or there might not be an accretion prism at all and serpentinite mélange from subduction channel is exposed directly at the surface (Fig. 14d).

Upward fluid percolation velocity $\left(v_{y \text { (percolation) }}\right)$ also imposes notable controls on accretion wedge evolution. Figure 14e,f shows the accretion wedge of the model ired (Fig. 2b), which was run with the default percolation velocity of $10 \mathrm{~cm} \mathrm{a}^{-1}$ (Fig. 14e) as well as with a significantly smaller velocity of $0.03 \mathrm{~cm} \mathrm{a}^{-1}$ (Fig. 14e). In the second case, fluids produced by sediment dehydration remain concentrated in the basal layer close to the slab, which is weakened and decoupled from the upper layer. As the upper layer is not weakened, nappe stacking of sediments is reduced and the undeformed area (plug) is laterally increased in comparison to the experiment with higher percolation velocity (cf. Fig. 14e,f). The different parts of the accretion wedge (nappes, plug, weak layer, Fig. 14a) can therefore be viewed as differently weakened sediments: strong sediments do not deform and form a plug. If fluids propagate quickly from the dehydration area above the slab, an overall weakening of the accretion wedge allows for stacking of sediments (Fig. 14e). If fluids propagate slowly, the dehydrating rocks retain their fluid. Thus, only local weakening of the lower sediments occurs and leads to the formation of a strongly deformed basal layer (Fig. 14f).

\section{Serpentinization of the forearc and seismic velocity structure}

In our numerical experiments, the 'cold nose' of the mantle wedge is continuously serpentinized during subduction. Here, the dehydration of the subducting slab provides large volumes of fluids to hydrate the mantle and, in addition, $P-T$ conditions are such that 
serpentinite and related hydrous minerals are stable (e.g. Schmidt \& Poli, 1998; Hyndman \& Peacock, 2003). In many cases, serpentinized mantle is mixed with subducted oceanic crust and sediments to form a tectonic mélange in the subduction channel (Figs 5d \& 11d). Hyndman \& Peacock (2003) gave several examples of forearcs where seismic velocity anomalies indicate serpentinization. In general, serpentinized mantle has lower seismic velocities and a higher Poisson's ratio, although a similar effect can be obtained with higher temperatures. But as the subducting oceanic plate cools, with the mantle wedge in the forearc region decreasing to $<400^{\circ} \mathrm{C}$, a negative seismic velocity anomaly in the forearc mantle wedge can be attributed to serpentinization (e.g. Bostock et al., 2002). Anhydrous mantle at this temperature has a P-wave velocity of $v_{\mathrm{p}} \geq 8.2 \mathrm{~km} \mathrm{~s}^{-1}$ whereas in forearcs commonly a value of $v_{\mathrm{p}}=7.8 \mathrm{~km} \mathrm{~s}^{-1}$ is normal. This reduced value of $v_{\mathrm{p}}$ can be explained by an average serpentinization of the forarc mantle of more than 15\% (Hyndman \& Peacock, 2003). Figure 15 shows the distribution of $v_{\mathrm{p}}$ velocity in the five reference models for different subduction regimes (Figs 3, 5, 8, $11 \& 12$ ) computed from model rock compositions on the basis of Gibbs energy minimization approach (Gerya et al., 2006). All models indicate lowered (7.2-
$7.8 \mathrm{~km} \mathrm{~s}^{-1}$ ) seismic velocity of the forearc mantle in the regions of serpentinization (Fig. 15), which is in good agreement with observed values (Hyndman \& Peacock, 2003).

Another prominent region of lowered seismic velocity in the mantle wedge is associated with hydrated partially molten thermal-chemical plume structures that form under the overriding plate (Fig. 15c-e). Similar seismic anomalies are indeed found in the central Andean subduction zone and are interpreted as complex patterns of fluid and melt transport in the mantle wedge (e.g. Schurr et al., 2003, 2006). According to recent experimental constraints, sedimentary plumes can generate silicic magmas and contribute strongly to magmatic activity at active margins including Cordilleran-type batholiths formation (Castro \& Gerya, 2008; Castro et al., 2009, 2010).

\section{Collisional mode of subduction}

As described in the section about the topographic evolution, in case of underplating plumes, stronger coupling of the plates leads to lithospheric thickening (e.g. Sobolev \& Babeyko, 2005) along with subduction erosion (Figs 4d, 11 \& 14d). Even some amount of
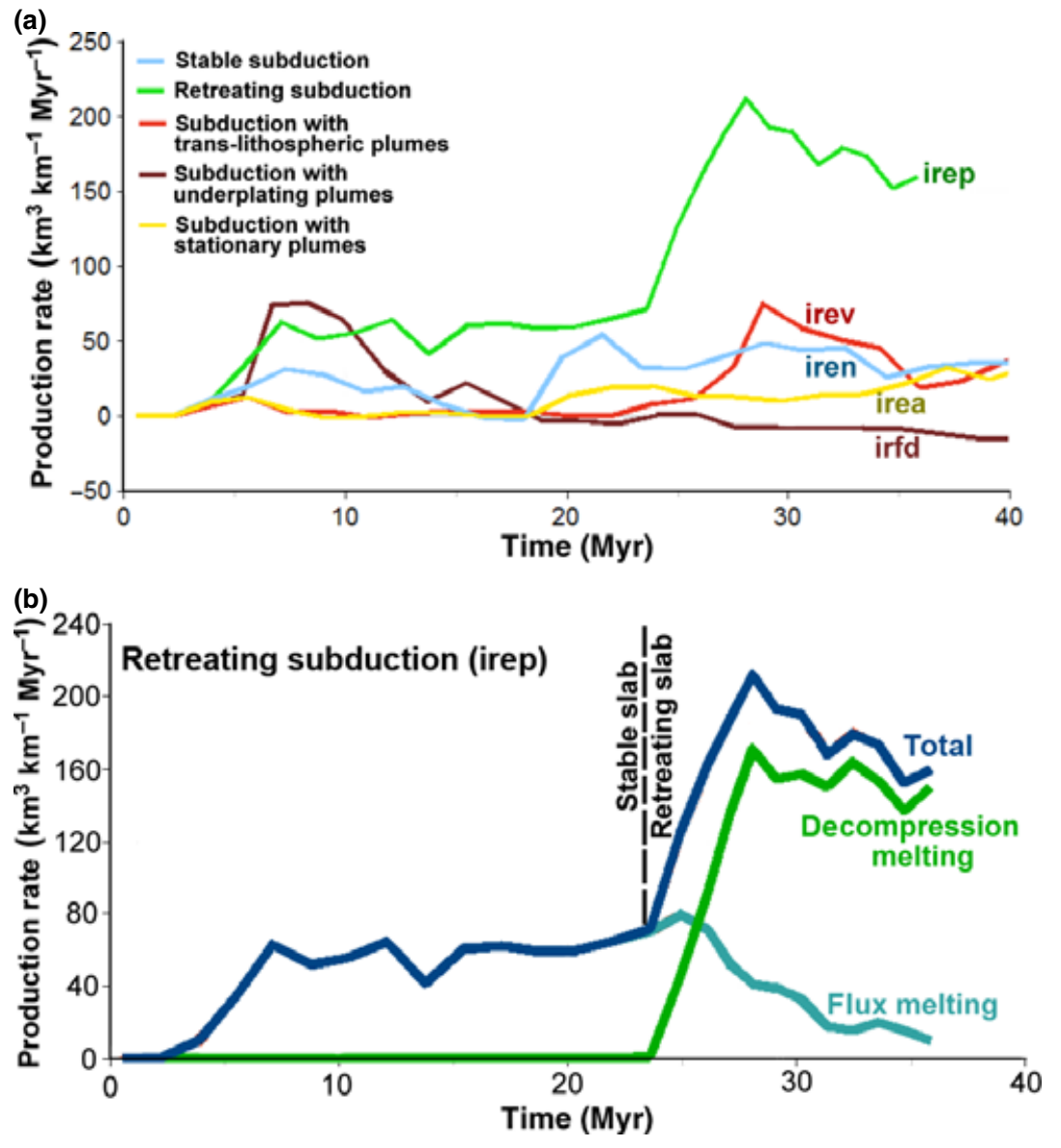

Fig. 13. (a) Crustal growth rates computed for five reference models and (b) relation between flux melting and decompression melting products for the retreating subduction regime. 
(a) Frontal accretion: nappe stacking

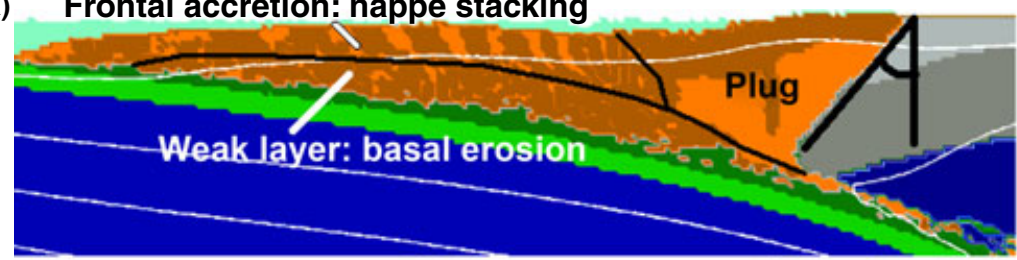

Model iren: $\lambda_{\text {fluid }}=\mathbf{0 . 0 0 1}$

(b)

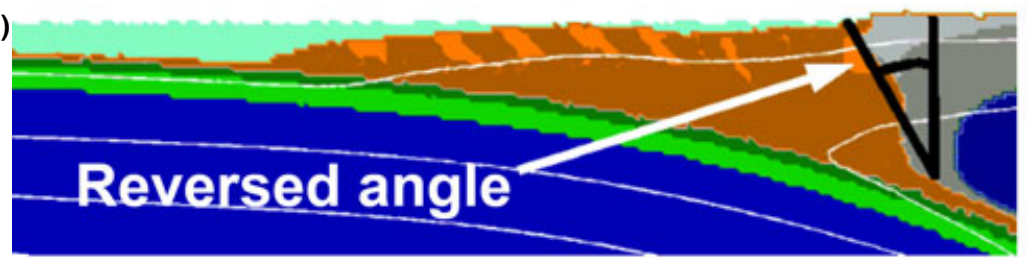

Model irea: $\lambda_{\text {fluid }}=0.1$

(c)

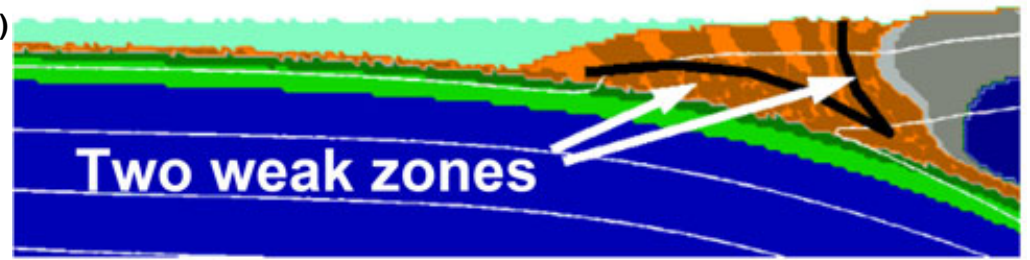

Model irfa: $\lambda_{\text {fluid }}=0.3$

(d)

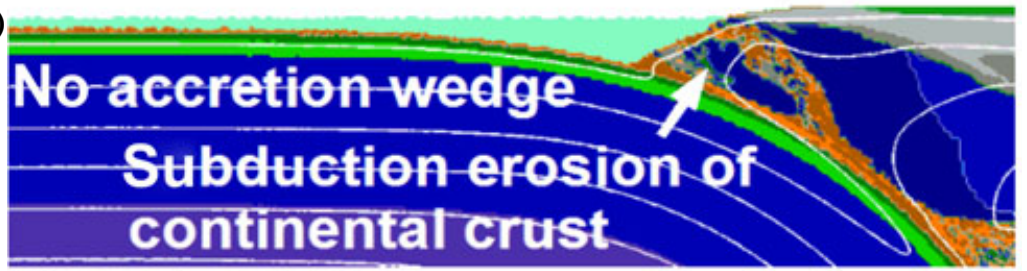
Model irfd: $\lambda_{\text {fluid }}=1$

Fig. 14. Influence of fluid-related weakening (a)-(d) and fluid percolation velocity (e)-(f) for the resulting geometry of accretion wedges in various subduction models (Fig. 2b). (e)

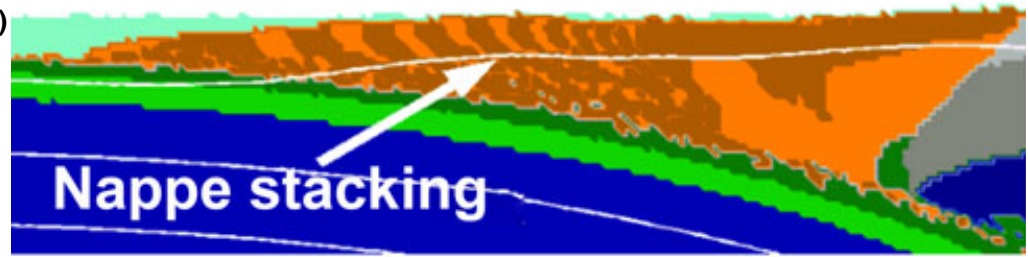

Model ired with $v_{y}$ (precolation) $=10 \mathrm{~cm} \mathrm{yr}^{-1}$

(f)

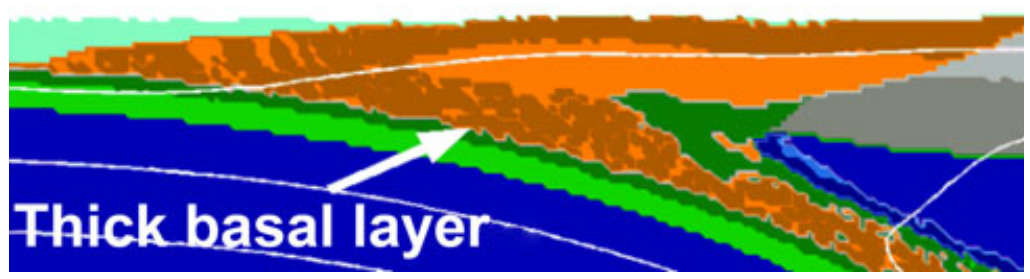

Model ired with $v_{y}$ (precolation) $=0.03 \mathrm{~cm} \mathrm{yr}^{-1}$ continental crust may be subducted. Towards the end of the simulated process, the magmatic arc on top of the continental plate migrates more and more towards the trench. Similar processes have been reconstructed for the subduction zone in the region of the southcentral Andes (Kay et al., 2005). There, the magmatic 

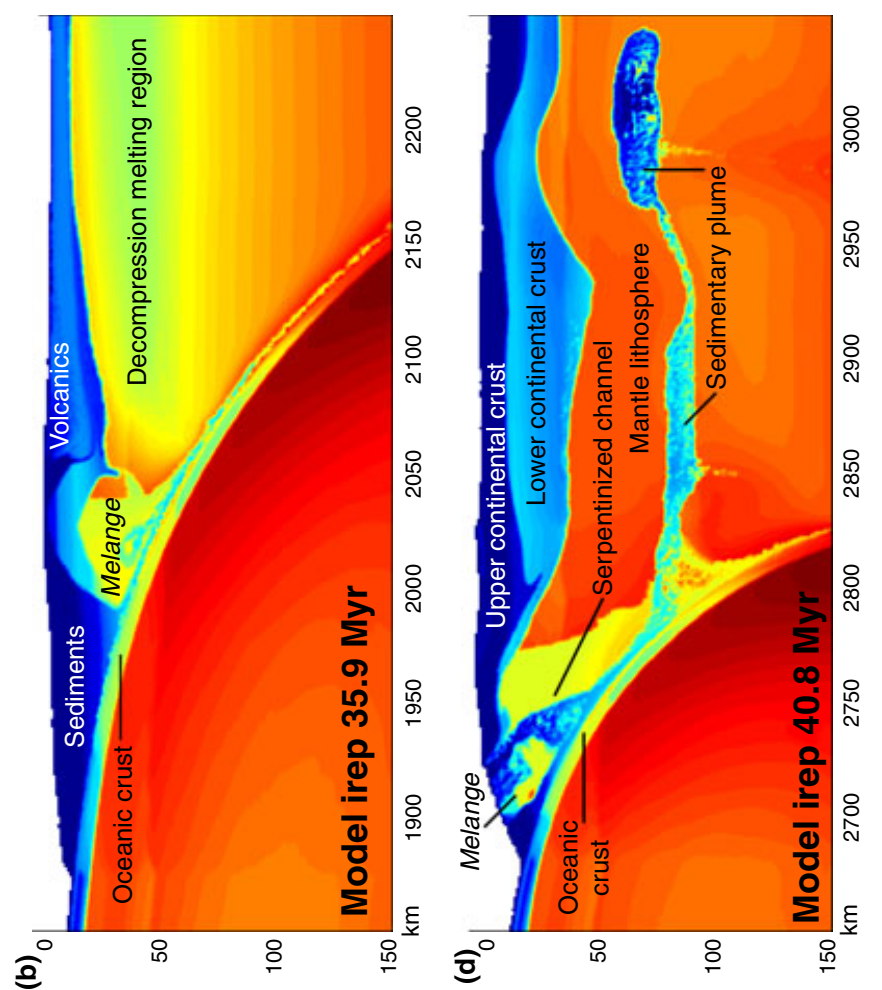

$$
\text { चั }
$$

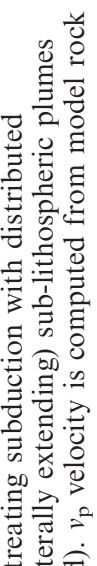

몰

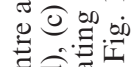

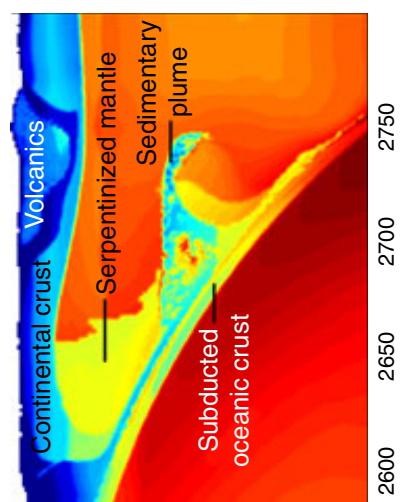

ปี่

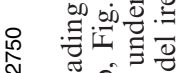

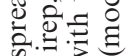

운

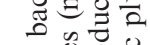

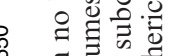

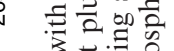

\&
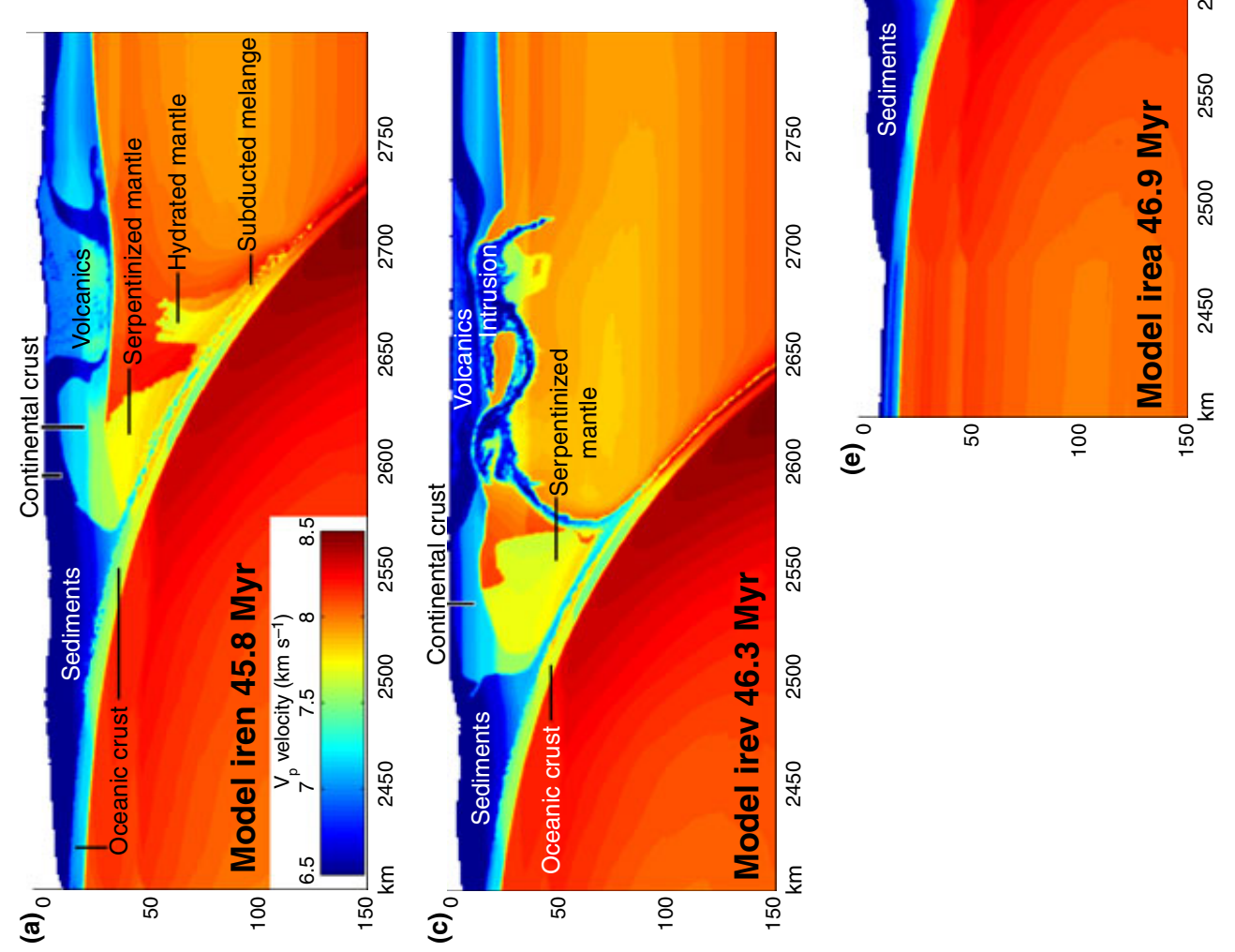

क्च च्चे

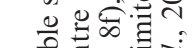

曾

ङ.

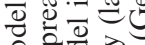

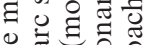

矛记

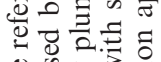

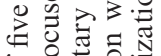

눙

品羊导自

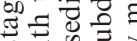

菏.

$\because$ क्षे

t?

कि ब्य

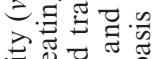

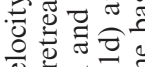

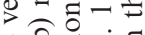

e.

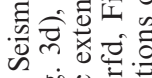

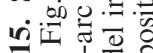

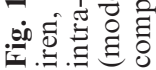


activity is coupled with tectonic processes as suggested by changes in production rates and chemical composition of the magmatic rocks in periods of crustal thickening and trench migration. In periods of crustal shortening, 'adakitic' magmas are produced whose chemical composition can be attributed to a combination of partial melting of the base of the thickened continental crust and melting of subducted crust. The reference model for underplating plumes provides a possible scenario. Here, strong coupling results in subduction erosion and the formation of a plume out of partially molten sediments and crust (both oceanic and continental). Furthermore, the collision-like subduction yields thickening and deformation of the continental lithosphere. During later stages of subduction, partial melting of the lower continental crust occurs. Thus, both required melt sources appear in this model. The trench-ward migration of the magmatic arc in our models is similar to observations summarized by Kay et al. (2005). In the model, the total shortening of the continental plate in the reference model for underplating plumes is $134 \mathrm{~km}$ in $47 \mathrm{Myr}$. In comparison, Kay et al. (2005) estimated even larger crustal shortening rates of the South American plate of $170 \mathrm{~km}$ in $20 \mathrm{Myr}$. This may suggest that strong coupling of the plates leads to increased compression and subduction erosion of the continental crust, although crustal shortening also depends on other physical parameters such as the subduction rate and the rheological structure of the overriding plate (e.g. Sobolev \& Babeyko, 2005; Faccenda et al., 2008).

Collisional subduction example is also described by Jiménez \& López-Velásquez (2008). According to their observations on the magmatism in the Huariana Belt in Bolivia, an extensional mode of subduction with formation of a backarc basin in the CambroOrdovician was followed by collisional subduction with uplift of an 'Altiplano' in the Neogene. This process was accompanied by trench migration and led to thinning of the lithosphere beneath the Huariana Belt and potentially magmatic addition beneath the 'Altiplano'.

\section{CONCLUSIONS}

In this study, the possible influences of rheological weakening from fluids and melts on the geodynamic regimes of subduction under an active margin are investigated numerically. Our experiments suggest that fluid-related weakening mainly affects the forearc region. Strong fluid-related weakening $\left(\lambda_{\text {fluid }}<0.01\right)$ promotes plate decoupling and reduces subduction drag, thus promoting growth of an accretion wedge. In contrast, reduced weakening by fluids $\left(\lambda_{\text {fluid }} \geq 0.1\right)$ results in strong plate coupling and leads to advancing collision-like subduction with enhanced subduction erosion. On the other hand, melts predominantly weaken the lithosphere below the arc that controls extension/shortening processes in the overriding plate.
Strong rheological weakening by melts in combination with low plate coupling triggers retreating subduction with a pronounced backarc spreading centre. Also, weakening of the continental lithosphere by melts extracted from trans-lithospheric sedimentary plumes generates a weak channel through which these structures may be emplaced into the crust below the arc. Based on our models the following five geodynamic regimes of subduction are identified, which may potentially form at active margins: (i) stable subduction with no backarc spreading centre and without plumes in the mantle wedge; (ii) retreating subduction with a focused backarc spreading centre and without plumes; (iii) retreating subduction with distributed intra-arc extension and trans-lithospheric sedimentary plumes; (iv) advancing subduction with underplating (laterally extending) sub-lithospheric plumes; and (v) stable to advancing subduction with stationary (laterally limited) sub-lithospheric plumes. Crustal growth rates computed from our models includes both flux melting and decompression melting products rates are comparable with natural estimates.

\section{ACKNOWLEDGEMENTS}

S. Buiter and an anonymous reviewer are thanked for suggestions and B. Kaus for discussions and comments. This work was supported by ETH Research Grants ETH-0807-2, ETH-0807-3, ETH-0609-2, SNF Research Grants 200020-126832, 200020-129487, SNF ProDoc program 4-D-Adamello and TopoEurope Program.

\section{REFERENCES}

Albarede, F., 1998. The growth of continental crust. Tectonophysics, 296, 1-14.

Arcay, D., Tric, E. \& Doin, M.P., 2005. Numerical simulations of subduction zones: effect of slab dehydration on the mantle wedge dynamics. Physics of the Earth and Planetary Interiors, 149, 133-153

Beaumont, C., Ellis, S. \& Pfiffner, A., 1999. Dynamics of sediment subduction-accretion at convergent margins: short-term modes, long-term deformation, and tectonic implications. Journal of Geophysical Research, 104, 17573-17601.

Bittner, D. \& Schmeling, H., 1995. Numerical modeling of melting processes and induced diapirism in the lower crust. Geophysical Journal International, 123, 59-70.

Bostock, M.G., Hyndman, R.D., Rondenay, S. \& Peacock, S.M., 2002. An inverted continental Moho and serpentinization of the forearc mantle. Nature, 417, 536-538.

Carlson, R.L. \& Miller, D.J., 2003. Mantle wedge water contents estimated from seismic velocities in partially serpentinized peridotites. Geophysical Research Letters, 30, 54-1-54-4 (article number: 1250).

Castro, A. \& Gerya, T.V., 2008. Magmatic implications of mantle wedge plumes: experimental study. Lithos, 103, 138148.

Castro, A., García-Casco, A., Fernández, C. et al., 2009. Ordovician ferrosilicic magmas: experimental evidence for ultrahigh temperatures affecting ametagreywacke source. Gondwana Research, 16, 622-632.

Castro, A., Gerya, T., Garcia-Casco, A. et al., 2010. Melting relations of MORB-sediment melanges in underplated mantle 
wedge plumes; implications for the origin of Cordilleran-type batholiths. Journal of Petrology, 51, 1267-1295.

Clauser, C. \& Huenges, E., 1995. Thermal conductivity of rocks and minerals. In: Rock Physics and Phase Relations. AGU Reference Shelf 3 (ed. Ahrens, T.J.), pp. 105-126. American Geophysical Union, Washington, DC.

Cloetingh, S.A.P.L., Wortel, M.J.R. \& Vlaar, N.J., 1982. Evolution of passive continental margins and initiation of subduction zones. Nature, 297, 139-142.

Connolly, J.A.D., 2005. Computation of phase equilibria by linear programming: a tool for geodynamic modeling and its application to subduction zone decarbonation. Earth and Planetary Science Letters, 236, 524-541.

Crameri, F. \& Kaus, B.J.P., 2010. Parameters that control lithospheric-scale thermal localization on terrestrial planets. Geophysical Research Letters, 37, 1-6 (article number: L09308).

Currie, C.A., Beaumont, C. \& Huismans, R.S., 2007. The fate of subducted sediments: a case for backarc intrusion and underplating. Geology, 35, 1111-1114.

Dimalanta, C., Taira, A., Yumul, G.P., Tokuyama, H. \& Mochizuki, K., 2002. New rates of western Pacific island arc magmatism from seismic and gravity data. Earth and Planetary Science Letters, 202, 105-115.

Doin, M.-P. \& Henry, P., 2001. Subduction initiation and continental crust recycling: the roles of rheology and eclogitization. Tectonophysics, 342, 163-191.

Elliott, T., Plank, T., Zindler, A., Wjite, W. \& Bourdon, B., 1997. Element transport from slab to volcanic front at the Mariana arc. Journal of Geophysical Research, 102, 1499115019.

Ellis, S.M., Beaumont, C. \& Pfiffner, O.A., 1999. Geodynamic models of crustal-scale episodic tectonic accretion and underplating in subduction zones. Journal of Geophysical Research, 104, 15169-15190.

Faccenda, M., Gerya, T.V. \& Chakraborty, S., 2008. Styles of post-subduction collisional orogeny: influence of convergence velocity, crustal rheology and radiogenic heat production. Lithos, 103, 257-287.

Faccenda, M., Gerya, T.V. \& Burlini, L., 2009. Deep slab hydration induced by bending related variations in tectonic pressure. Nature Geoscience, 2, 790-793.

Gerya, T.V. \& Yuen, D.A., 2003a. Rayleigh-Taylor instabilities from hydration and melting propel cold plumes at subduction zones. Earth and Planetary Science Letters, 212, 47-62.

Gerya, T.V. \& Yuen, D.A., 2003b. Characteristics-based marker-in-cell method with conservative finite-differences schemes for modeling geological flows with strongly variable transport properties. Physics of the Earth and Planetary Interiors, 140, 293-318.

Gerya, T.V., Stoeckhert, B. \& Perchuk, A.L., 2002. Exhumation of high-pressure metamorphic rocks in a subduction channel a numerical simulation. Tectonics, 21, 6-1-6-15 (article number: 1056)

Gerya, T.V., Yuen, D.A. \& Sevre, E.O.D., 2004. Dynamical causes for incipient magma chambers above slabs. Geology, 32, 89-92.

Gerya, T.V., Connolly, J.A.D., Yuen, D.A., Gorczyk, W. \& Capel, A.M., 2006. Seismic implications of mantle wedge plumes. Physics of the Earth and Planetary Interiors, 156, 5974.

Gerya, T.V., Connolly, J.A.D. \& Yuen, D.A., 2008. Why is terrestrial subduction one-sided? Geology, 36, 43-46.

Gorczyk, W., Willner, A.P., Gerya, T.V., Connolly, J.A.D. \& Burg, J.-P., 2007. Physical controls of magmatic productivity at Pacific-type convergent margins: numerical modelling. Physics of the Earth and Planetary Interiors, 163, 209-232.

Gutscher, M.-A., Kukowsky, N., Malavieille, J. \& Lallemand, S., 1998. Material transfer in accretionary wedges from analysis of a systematic series of analog experiments. Journal of Structural Geology, 20, 407-416.

Hassani, R., Jongmans, D. \& Chery, J., 1997. Study of plate deformation and stress in subduction processes using two-dimensional numerical models. Journal of Geophysical Research, 102, 17951-17965.

Hawkesworth, C.J., Turner, S.P., McDermott, F., Peate, D.W. \& vanCalsteren, P., 1997. U-Th isotopes in arc magmas: implications for element transfer from the subducted crust. Science, 276, 551-555.

Hebert, L.B., Antoshechkina, P., Asimow, P. \& Gurnis, M., 2009. Emergence of a low-viscosity channel in subduction zones through the coupling of mantle flow and thermodynamics. Earth and Planetary Science Letters, 278, 243-256.

Hess, P.C., 1989. Origin of Igneous Rocks. Harward University Press, London, UK.

Hirschmann, M.M., 2000. Mantle solidus: experimental constraints and the effects of peridotite composition. Geochemistry Geophysics Geosystems, 1, 1-21 (article number: 1042).

Hofmeister, A.M., 1999. Mantle values of thermal conductivity and the geotherm from phonon lifetimes. Science, 283, 16991706.

Holbrook, W.S., Lizarralde, D., McGeary, S., Bangs, N. \& Diebold, J., 1999. Structure and composition of Aleutian island arc and implications for continental crustal growth. Geology, 27, 31-34.

Honda, S., Gerya, T. \& Zhu, G., 2010. A simple three-dimensional model of thermo-chemical convection in the mantle wedge. Earth and Planetary Science Letters, 290, 311-318.

Hyndman, R.D. \& Peacock, S.M., 2003. Serpentinization of the forearc mantle. Earth and Planetary Science Letters, 212, 417 432.

Jiménez, N. \& López-Velásquez, S., 2008. Magmatism in the Huarina belt, Bolivia, and its geotectonic implications. Tectonophysics, 459, 85-106.

Johannes, W., 1985. The significance of experimental studies for the formation of migmatites. In: Migmatites (ed. Ashworth, J.R.), pp. 36-85. Blackie, Glasgow, UK.

Johnson, H.P. \& Pruis, M.J., 2003. Fluxes of fluid and heat from the oceanic crustal reservoir. Earth and Planetary Science Letters, 216, 565-574.

Karato, S. \& Wu, P., 1993. Rheology of the upper mantle: a synthesis. Science, 260, 771-778.

Kaus, B.J.P. \& Podladchikov, Y.Y., 2006. Initiation of localized shear zones in viscoelastoplastic rocks. Journal of Geophysical Research, 111, 1-18 (article number: B04412).

Kaus, B.J.P., Steedman, C. \& Becker, T.W., 2008. From passive continental margin to mountain belt: insights from analytical and numerical models and application to Taiwan. Physics of the Earth and Planetary Interiors, 171, 235-251.

Kay, S., Godoy, E. \& Kurtz, A., 2005. Episodic arc migration, crustal thickening, subduction erosion, and magmatism in the south-central Andes. Geological Society of America Bulletin, 117, 679-688.

Kelley, K.A., Plank, T., Grove, T.L., Stolper, E.M., Newman, S. \& Hauri, E., 2006. Mantle melting as a function of water content beneath back-arc basins. Journal of Geophysical Research, 111, 1-27 (article number: B09208).

Kushiro, I., Syono, Y. \& Akimoto, S., 1968. Melting of a peridotite nodule at high pressures and high water pressures. Journal of Geophysical Research, 73, 6023-6029.

Mackwell, S.J., Zimmerman, M.E. \& Kohlstedt, D.L., 1998. High- temperature deformation of dry diabase with application to tectonics on Venus. Journal of Geophysical Research, 103, 975-984.

Nikolaeva, K., Gerya, T.V. \& Connolly, J.A.D., 2008. Numerical modelling of crustal growth in intraoceanic volcanic arcs. Physics of the Earth and Planetary Interiors, 171, 336356.

Nikolaeva, K., Gerya, T.V. \& Marques, F.O., 2010. Subduction initiation at passive margins: numerical modeling. Journal of Geophysical Research, 115, 1-19 (article number: B03406).

Poli, S. \& Schmidt, M.W., 1995. $\mathrm{H}_{2} \mathrm{O}$ transport and release in subduction zones: experimental constraints on basaltic and andesitic systems. Journal of Geophysical Research, 100, 22299-22314. 
Poli, S. \& Schmidt, M.W., 2002. Petrology of subducted slabs. Annual Review of Earth and Planetary Sciences, 30, 207-235.

Ranalli, G., 1995. Rheology of the Earth. Chapman and Hall, London, UK.

Regenauer-Lieb, K., Yuen, D.A. \& Branlund, J., 2001. The initiation of subduction: critically by addition of water? Science, 294, 578-580.

Reymer, A. \& Schubert, G., 1984. Phanerozoic addition rates to the continental crust and crustal growth. Tectonics, 3, 6377.

Schmeling, H., Babeyko, A.Y., Enns, A. et al., 2008. A benchmark comparison of spontaneous subduction models towards a free surface. Physics of the Earth and Planetary Interiors, 171, 198-223.

Schmidt, M.W. \& Poli, S., 1998. Experimentally based water budgets for dehydrating slabs and consequences for arc magma generation. Earth and Planetary Science Letters, 163, 361-379.

Schurr, B., Asch, G., Rietbrock, A., Trumbull, R. \& Haberland, C., 2003. Complex patterns of fluid and melt transport in the central Andean Subduction zone revealed by attenuation tomography. Earth and Planetary Science Letters, 215, 105119.

Schurr, B., Rietbrock, A., Asch, G., Kind, R. \& Oncken, O., 2006. Evidence for lithospheric detachment in the central Andes from local earthquake tomography. Tectonophysics, 415, 203-223.

Selzer, C., Buiter, S.J.H. \& Pfiffner, O.A., 2008. Numerical modeling of frontal and basal accretion at collisional margins. Tectonics, 27, 1-26 (article number: TC3001).

Sibson, R.H., 1990. Faulting and fluid flow. In: Fluids in Tectonically Active Regimes of the Continental Crust (ed. Nesbitt, B.E.), pp. 92-132. Mineralogical Association of Canada, Vancouver, Canada.

Sizova, E., Gerya, T., Brown, M. \& Perchuk, L.L., 2010. Subduction styles in the Precambrian: insight from numerical experiments. Lithos, 116, 209-229.
Sobolev, S.V. \& Babeyko, A.Y., 2005. What drives orogeny in the Andes? Geology, 33, 617-620.

Stein, M. \& Ben-Avraham, Z., 2007. Mechanism of continental crust growth. Treatise on Geophysics, 9, 171-195.

Stern, R.J., 2002. Subduction zones. Reviews of Geophysisics, 40, 3-1-3-13 (article number: 1012).

Stern, R.J. \& Bloomer, S.H., 1992. Subduction zone infancy: examples from the Eocene Izu-Bonin-Mariana and Jurassic California arcs. Geological Society of America Bulletin, 104, 1621-1636.

Stolper, E. \& Newman, S., 1994. The role of water in the petrogenesis of Marina trough magmas. Earth and Planetary Science Letters, 121, 293-325.

Taira, A., Saito, S., Aoike, K. et al., 1998. Nature and growth rate of the Northern Izu-Bonin (Ogasawara) arc crust and their implications for continental crust formation. The Island Arc, 7, 395-407.

van Thienen, P., Vlaar, N.J. \& van den Berg, A.P., 2004. Plate tectonics on the terrestrial planets. Physics of the Earth and Planetary Interiors, 142, 61-74.

Turcotte, D.L. \& Schubert, G., 2002. Geodynamics. Cambridge University Press, Cambridge, UK.

Ueda, K., Gerya, T. \& Sobolev, S.V., 2008. Subduction initiation by thermal-chemical plumes. Physics of the Earth and Planetary Interiors, 171, 296-312.

Yamato, P., Burov, E., Agard, P., Le Pourhiet, L. \& Jolivet, L., 2008. HP-UHP exhumation during slow continental subduction: self-consistent thermodynamically and thermomechanically coupled model with application to the Western Alps. Earth and Planetary Science Letters, 271, 63-74.

Zhu, G., Gerya, T.V., Yuen, D.A., Honda, S., Yoshida, T. \& Connolly, J.A.D., 2009. 3-D Dynamics of hydrous thermalchemical plumes in oceanic subduction zones. Geochemistry Geophysics Geosystems, 10, 1-20 (article number: Q11006).

Received 20 November 2009; revision accepted 14 August 2010. 